\title{
A SURVEY OF NETWORK TELEVISION'S COVERAGE OF THE WAR
} IN VIETNAM

\author{
A Thesis \\ Presented to
}

the Faculty of the Graduate School

University of Missouri

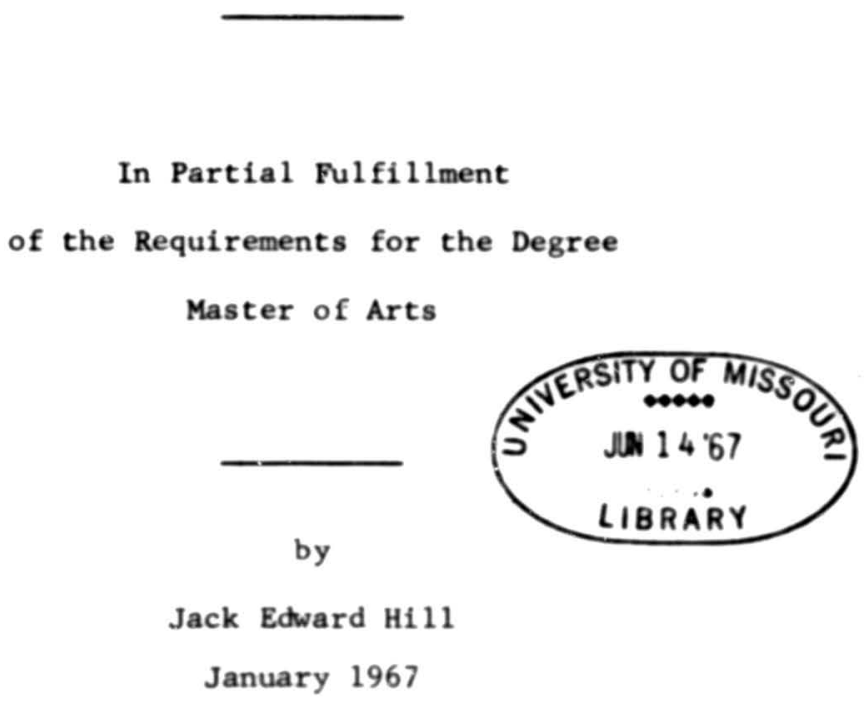


The undersigned, appointed by the Dean of the Graduate Faculty, have examined a thesis entitled

\section{A SURVEY OF NETWORK TELEVIS ION'S \\ COVERAGE OF THE WAR \\ IN VIETNAM}

presented by Jack Edward Hill

a candidate for the degree of Master of Arts

and hereby certify that in their opinion it is worthy of acceptance.

Signatures redacted. 


\section{ACKNOWLEDGMENTS}

In selecting the coverage of the war in Vietnam by network television as a thesis topic, the researcher is hampered to a degree by the current nature of the subject. As a result, one of the chief sources of information for this study was through letters of inquiry. These were written to a number of people who deal with network TV's coverage of this war every day: to television newsmen themselves, to government and military spokesmen, and to press crities.

The writer was concerned that after many weeks of research, enough material on such a current topic still might not have been found to justify the study. Therefore, a good response to his letters of inquiry was most important. That response was forthcoming, and a note of thanks certainly is justified to the busy people who took the time to reply. For without their help, this research effort would not have seen fruition.

Space does not allow a listing of all the people to whom the writer is indebted, but a special note of thanks is due Ron Steinman of $\mathrm{NBC}$ and to Peter Herford of CBS, 
Saigon bureau chiefs of their respective networks. Of the many persons to whom letters of question were written, these men must have been among the busiest of all. Yet, they found time to write thorough answers to the questions asked. This information was most helpful.

Another person who was very cooperative in providing valuable material was Kenneth $R$. Wilson, administrator of the New York Chapter of the National Academy of Television Arts and Sciences. He tracked down the audio tapes of a forum conducted by his organization on TV's coverage of the Vietnamese situation and thoughtfully provided these for the author's ronvenience.

And finally a note of appreciation also is extended to Dr. Edward C. Lambert, the writer's chief advisor, for his encouragement and supervision throughout this research effort. 
TABLE OF CONTENTS

CHAPTER

PAGE

I. AN INTRODUCTION TO THE STUDY . . . . . . . . 1

The Problem ................ 3

Statement of the problem . . . . . . . 3

Importance of the study . . . . . . . . 3

Television War Coverage: Past

and Present... . . . . . . . . . 5

The Method of Procedure . . . . . . . . . 7

Sources of Data . . . . . . . . . 7

Limitations of the study . . . . . . . 9

Weaknesses of the study . . . . . . . . 9

Organization of the study ........ . 11

II. HOW THE WAR IS COVERED . . . . . . . . . 13

On The Scene . . . . . . . . . . . . 14

Covering the military conflict . . . . 14

Covering the political conflict. . . . 25

Letters from Vietnam . . . . . . . . 29

The Men Who Cover the War . . . . . . . 31

How many are there . . . . . . . . . 33 
Qualifications . . . . . . . . .

Lack of experienced personnel . . . . .

News management . . . . . . . . . .

Rest and recreation ......... . 38

The cost . . . . . . . . . . 39

Getting the film home .......... 40

How the film is used ........ 43

Summary ............... 47

III. CENSORSHIP AND PRESS RELATIONS . . . . . . . 49

Restrictions ........... 50

Press relations ........... 53

Summary .............. . 61

IV. EXAMPLES OF WHAT THE VIEWER CAN SEE . . . . . 64

Chopper warfare . . . . . . . . 65

The burning of Cam Ne ....... 66

Vietnam perspective . . . . . . . 69

The Colonel loses a leg........ 73

The Fulbright hearings . . . . . . 76

Eric Sevareid on Vietnam . . . . . . 81

A father interviews his son ...... 83

Summary . . . . . . . . . . 85 
CHAPTER

PAGE

v. TV's COVERAGE OF VIETNAM: WHAT

PEOPLE SAY ABOUT IT . . . . . . . . . . . 87

What U.S. government and military

spokesmen say . . . . . . . . . . . . 96

What the television newsmen say . . . . 107

Summary . . . . . . . . . . . . . 111

VI. FINAL SUMMARY AND CONCLUSIONS . . . . . . . . 114

Summary . . . . . . . . . . . . . . 114

Highlights of the study . . . . . . . . . 114

Conclusions . . . . . . . . . . . . . 119

Is the coverage adequate? . . . . . . . 119

Honesty and objectivity . . . . . . . . 124

Is anyone getting the message? . . . . . 127

What the future will bring . . . . . 128

Related areas for stućy . . . . . . . 132

A final thought ............ 136

APPENDIX A . . . . . . . . . . . . . . . . . . . 139

APPENDIX B . . . . . . . . . . . . . . . 143

APPENDIX C . . . . . . . . . . . . . . . 147

APPENDIX D . . . . . . . . . . . . . . 152

BIBLIOGRAPHY . . . . . . . . . . . . . . . 155 
v. TV'S COVERAGE OF VIETNAM: WHAT PEOPLE

SAY ABOUT IT . . . . . . . . . . .

What the critics say . . . . . . . .

What U.S. government and military spokesmen say . . . . . . . . . . .

What the television newsmen say . . . .

Summary . . . . . . . . . . . . .

vI. FINAL SUMMARY AND CONCLUSIONS . . . . . . .

Sumnary . . . . . . . . . . . . . .

Highlights of the study . . . . . . .

Conclusions . . . . . . . . . . . . .

Is the coverage adequate? . . . . . . .

Honesty and objectivity . . . . . . .

Is anyone getting the message? . . . .

What the future will tring . . . . .

Related areas for study . . . . . . .

A final thought . . . . . . . . . 136

APPENDIX A . . . . . . . . . . . . . . . . . . . 
CHAPTER I

\section{AN INTRODUCTION TO THE STUDY}

The war in Vietnam has become the overriding fact in the national 11 fe of the United States. As such it is probably the most complex and difficult war to present and interpret that the American press ever has covered. This is especially true for network television, because vietnam is television's first war.

Now Americans in their own homes can get a close-up of a distant war almost before the echoes die on the battlefield. But back home viewers and government officials do not always like what they see. And there is a continuing debate over whether TV, the most dramatic of the news media, is giving the U.S. the big picture or the small one of a war that has kept the nation puzzled and disturbed.

Probably no medium gets the whole story of Vietnam. But the black and white or color picture presented by the nation's three TV networks has such a tremendous impact that whatever it shows becomes a very powerful and memorable event. As a result, network television gets special scrutiny 
in its handling of the sensitive and intricate story that vietnam has become.

Not only is it a particularly difficult war for the TV newsmen on the scene, but the fighting in Vietnam and its political aspects present an endlessly perplexing issue that bedevils the television editors at home. Still, the networks' coverage of the war continues to increase, not so much for the sake of the ratings, but for that elusive but al1 important thing called network prestige. And because of this as noted by Dr. Frank Stanton, President of the Columbia Broadcasting System:

War has ceased to be a far-off thing of cold casualty statistics, unpronounceable geographical names, and unread speeches by unknown statesmen. The misery of war, the pain, the death, the fear, the drudgery . . . all these are brought fullscale to the people with whom the final responsibility for national commitments in a democratic society rests. 1

$1^{1}$ President Frank Stanton, of CBS, "The Face of War," a speech at the Waldorf-Astoria Hote1, New York City, January 28, 1966. 


\section{THE PROBLEM}

Statement of the problem. In genera1 terms the purpose of this study was to survey the coverage of the war in Vietnam by network television.

More specifically the study was directed (1) to defining the problems that affect the networks' ability to cover this war; (2) to learning how the critics, the military, and the television industry evaluate the war coverage; and (3) to reaching some conclusions on the performance of network television in its coverage of this conflict.

Importance of the study. According to TV Guide, almost 60 per cent of all Americans now get most of their news about vietnam from network television. ${ }^{2}$ War always has posed new responsibilities and opportunities on the news media. But the war in Vietnam marks the first time that both the immediacy and full influence of television have been significant factors in the development of public opinion

2 Neil Hickey, "The Vietnam War: Is Television Giving Us the Picture?", TV Guide, XIV (October 1, 1966), p. 8. 
in time of a serious crisis. As Jack Gould, broadcasting critic of The New York Times, pointed out:

For many millions on the home front who have never seen the horrors of war at first hand, the nightly exposure to suffering and death on the TV screen must be recognized as possibly one factor in the national uneasiness over future policies in Vietnam . . . the constant evening reminder of war's consequences tears the heart in visual terms not heretofore experienced in wars involving the United States.

In every war public opinion has been a major and often the dominant factor in the outcome. But in the case of an undeclared war such as Vietnam, public opinion becomes even more important, and the way in which this conflict is reported, with its effect on American public opinion, could win or lose the war, regardless of what happens in the jungle battles. 4

With more than $70,000,000$ TV sets now bringing the arguments about the war in Vietnam into almost every Ameri-

3Jack Gould, "Crisis in Need of Commentary," The New

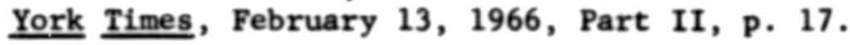

${ }^{4}$ Hanson W. Baldwin, "The Information War in Saigon," The Reporter, XXXIV (February 24, 1966), p. 29. 
can home, ${ }^{5}$ where the audience generally numbers three or four, network television has become the single most important element in the formation of public opinion about this conflict.

It is no secret that Peking's and Hanoi's hopes for victory in Vietnam are keyed to winning this battle of public opinion. ${ }^{6}$ with its vast audience and great impact, the importance of network television in this battle of American public opinion cannot be overestimated.

\section{TELEVISION WAR COVERAGE: PAST AND PRESENT}

Al1 wars have had their reporters, and each American correspondent in his own time has faced innovations. Today in Vietnam the innovation is the portable motion picture sound camera up front with the troops.

With this equipment the TV crews are able to cover what has become television's first war. World War II ended before the advent of nation-wide television. During the

SNeil Hickey, "Vietnam: Is Television Giving Us the Picture?", IV Guide, XIV (October 8, 1966), p. 26.

6aldwin, ㅇ․ cit., p. 29. 
Korean War there were only about $10,000,000$ TV homes, and television's role in that conflict was, therefore, relatively unimportant. But today Vietnam can be seen on more than 70,000,000 American TV screens. No distant war was ever brought so close to so many and in such great detail. To most Americans the obliteration of entire cities in Germany and Japan in World War II were little more than cold newspaper headlines and radio bulletins. But now because of the coverage of the war in Vietnam by network television, the burning of a tiny hamlet is observable in almost any living room 36 hours after it takes place.

However, TV in Vietnam is still feeling its way. As Lou Cioffi, ABC Far East Correspondent, noted, "Television has nothing in its history to prapare it for this kind of story. $" 7$

But now the three American TV networks are sparing little in effort and expense in learning how to cover the Vietnam war. Three years ago fewer than a dozen men from al1 the media covered the conflict, and as late as 1964 , none of the TV networks even had a full-time correspondent

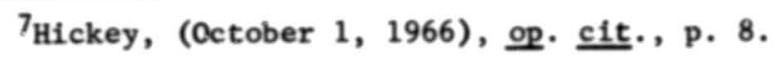


in Vietnam. Then with the American troop build-up starting in the fall of 1965 , the press corps grew accordingly. NBC was the first to set up a permanent bureau in Saigon, headed initially by 25-year-old Garrick Utley. Then CBS followed with Morley Safer, who was pulled out of London. Next, ABC signed on Malcolm Browne, Pulitzer Prize-winning former Associated Press reporter, as its full-time man in Saigon. And on a list a year later that showed the names of 400 accredited journalists in Vietnam, 82 of them were with the three American television networks. ${ }^{8}$

\section{THE METHOD OF PROCEDURE}

Sources of Data. At the time of this writing, the war in Vietnam is still a fact that plagues the national life of the United States. As a result of the current nature of the topic, the only readily available sources of information were periodicals, newspapers, and recent speeches relating to TV's efforts in Vietnam.

Much of the material was found in various broadcasting

${ }^{8}$ Neil Hickey, (October 8, 1966), ㅇ․ 소., p. 26. 
and trade journals. Current news magazines with their sections on the press and broadcasting also provided valuable background. In addition, these sources gave leads to other origins of information: to a number of speeches relating to the topic and to a set of tapes on a forum by the New York Chapter of the National Academy of Television Arts and Sciences, "Television War Correspondent: The New Breed."

As the research through these sources continued, other questions were raised, the answers to which were not readily available. The only way in which these additional questions could be answered was by writing letters of inquiry to the people who, because of their position, could best provide the needed information. Therefore, personal letters were written to various authorities in the networks; to press officers of the government and military; and also to several broadcasting critics. Altogether, 44 different letters were written, each asking specific questions of the individual to whom it was addressed. Thirty-five replies were received, a return ratio of nearly 80 per cent.

Some were extremely short and to the point and others very detailed. 
Limitations of the study. At the time of this writing, no similar studies of network television's coverage of the war in Vietnam had yet been attempted. As a result the whole scope of the problem was before the researcher. Therefore, it was decided that the best approach in covering this subject would be to survey the topic in general terms. Hopefully, later researchers would be able to use this work as a foundation for more specific studies of TV's coverage of the war and 1ts effects on the American audience.

This study is limited, however, in that it refers only to network television's coverage of the situation in Vietnam. Network TV also has spent considerable time in covering related stories which have developed outside Vietnam: the national uneasiness over the draft and the peace demonstrations in this country, for example. But a consideration of the networks' coverage of these related stories was beyond the scope of this study.

Weaknesses of the study. Because of the current nature of the topic, the answers to many of the questions involved were not readily available to the researcher. Writing letters of inquiry was not a complete solution, 
because it is difficult to communicate fully in a few typewritten lines. Obviously, a number of the replies really did not provide the answers for which the researcher was looking. Follow-up letters could not be utilized in these cases because of the expense involved and because of the length of time generally necessary for a reply.

Certainly a dialogue with those concerned with network television's coverage of the war would have been much more effective. Because of the complexity of reaching these officials and newsmen, however, this approach was not financially feasible. An additional weakness to a study of this type was pointed out by Saigon Bureau Chief for CBS News, Peter Herford:

Your research must perforce be woefully incomplete unless you manage to spend at least six months in the network shops in New York, and at least a year in vietnam. Or . . . you will accumulate a great deal of opinion, and a paucity of fact. The "facts" are hard to come by.

The writer must concede that Herford's point does have some validity. Certainly a thesis of this type cannot provide all the answers, but it is a beginning.

${ }^{9}$ Personal letter from Peter M. Herford, Saigon Bureau Chief, CBS News, dated October 15, 1966. 
organization of the remainder of the thesis. The rest of this study is organized into five other chapters. Chapter II, "How the War Is Covered," explains how the networks are able to get on-the-scene material. The chapter also points out the particular problems that Vietnam presents for the TV networks and introduces the reader to the men who cover this story for television.

The third chapter is devoted to a survey of the difficulties created by the problems of censorship and press relations in Vietnam. Both affect the other media as much as they do television, but these problems involve an area the researcher felt deserved a separate chapter to make this study more complete.

"Examples of What the Viewer Can See" is the title of the fourth chapter, and it is included to give the reader an idea of what is produced when the networks' Vietnam product is shown on the screens of America's 70,000,000 TV sets.

The fifth chapter of this study is given to an assessment of network television's Vietnam coverage by those who are the most concerned with it: the critics, spokesmen for the government and the military, and the TV newsmen themselves. 
The purpose of the last chapter is to tie together the loose ends that remain, but primarily it is to provide some final conclusions about network TV's coverage of this conflict.

From the material which thus has been compiled, the information on the following pages is presented in the hope of broadening the reader's knowledge and understanding of the coverage of the war in Vietnam by network television. 


\section{CHAPTER II}

\section{HOW THE WAR IS COVERED}

In past wars in which the United States has been involved, newsmen have been able to report accomplishments in terms of hills and road junctions taken, eities occupied, and miles gained. But the confilct in vietnam is pretty much a guerrilla war. As a result, newsmen have found it much more difficult to report in tangible terms.

There are no frontines in Vietnam; the war is fought at the same time all over the country at scores of different places. No one has yet come up with a set of rules for fighting such a war, and thus there are few guidelines for newsmen to follow in reporting it. This is especially true for the television networks, since Vietnam is TV's first war. But in addition, Vietnam poses special problems for television, beyond those faced by the other media, which greatly influence the networks' ability to cover the story. The purpose of this chapter is (1) to relate how the conflict is covered by network TV; (2) to cover the particular problems that the networks face in Vietnam; and (3) to 
introduce the men who report this story for the TV networks.

\section{ON THE SCENE}

Covering the Military Conflict. Unlike the men who work in Vietnam for the other media, the networks' camera crews can't get a "fill-in" from someone else to cover what they might have missed. The newspaper or magazine reporter can write a magnificent account of a battle he missed by several hours. But television is a picture medium, and so the TV reporter has to be there when it happens, or he won't have a story. As a result, some of the network newsmen have been on more operations than many soldiers.

The picture that network television gets from the field in Vietnam often depends upon a combination of uncanny luck and canny connections. The only exception occurs when the military notify newsmen in advance of a major campaign. But frequently, getting significant battle pictures is simply a matter of good fortune.

Providing transportation for the network crews in Vietnam falls mainly on the Air Force and Army. The Air Force furnishes a number of planes, available on a scheduled basis, for routine daily movement of newsmen. But they are 
frequently not going the right way at the right time, especially when a battle erupts. Then special arrangements have to be made.

The networks also depend heavily on Army helicopters .

Peter Kalischer, CBS News Far East correspondent, noted:

There are one, sometimes, two, press helicopters; so naturally it's a constant fight for space. We tell them CBS wants to go, and the first thing they try to do is knock off the soundman . . . We make our own deals with American and Vietnamese pilots. Away from Saigon and the battle of red tape, it's easier to hiteh rides. 10

There is strong competition among the network crews in the field in Vietnam, and sometimes a crew from each of the three networks will show up for the same operation. When that happens the crew on the scene first gets its pick of the aircraft or the unit which it will accompany.

After a while the experienced hands get to know the "hot" units, the ones with which the best stories are likely to occur. But once a television crew has committed itself on a military mission, it usually must stay on until the operation is completed. The crew hopes to get shot at, or

10 Albert Kroeger, "Television's Men At War," Television, XXII (July, 1965), p. 38. 
else it won't have a story. But if that is not the case, the men rarely can jump in a jeep and look somewhere else for a battle. There are few jeeps and even fewer roads in the jungle.

For all the news media, the logistical problems in Vietnam are among the most difficult. Charles Arnot, ABC News Southeast Asia correspondent, said that covering the war is "90 per cent logistics, 10 per cent journalism."11 Ron Steinman, Saigon Bureau Chief for NBC News, indicated that fully 50 per cent of the time his people spent in the field was on airplanes or in helicopters and jeeps. 12

Although the military provides transportation for the long distance moves in Vietnam, the TV crew still has to spend long hours walking if it is to get the story on film. This is where the television crew really earns its pay, because the TV "pencil" may weigh several hundred pounds, consisting of camera, film, and sound gear worth possibly as much as $\$ 10,000$. In addition, the men must carry their own

\section{${ }^{11}$ Ibid.}

12 Personal letter from Ron Steinman, Saigon Bureau Chief, NBC News, dated October 12, 1966. 
water, rations, poncho, and sometimes a weapon.

Probably the most typical part of a television crew's iife in Vietnam is something called the "walk in the sun" story. Murray Fromson, CBS News correspondent, gave an example:

Near Chu Lai, I walked for six hours in 130 degree heat. Sixty Marines fell to heat prostration, but there was no significant contact with unfriendly forces. No story. ${ }^{13}$ Another example was provided by Dan Rather, also a CBS correspondent:

For four days we walked with the Marines near Danang without finding the Vietcong. A major apologized for the lack of action, but said, 'Tomorrow the chances are quite good.' We were up at 3 A.M., moved out before dawn, walked $17 \mathrm{kilometers}$ and reached a South Vietnamese Army outpost which had already been wiped out. So all I got was one hundred feet of an aftermath story. No battle footage. 14

But when battle scenes are captured on $\mathrm{film}$, other

problems are created. CBS's Peter Herford explained:

We begin with the eye of the camera. It photographs only what it sees which is a more limited field of vision than the human eye,

13Hickey, (October 8, 1966), 오. cit., p. 13.

${ }^{14}$ Ibid. 
and it doesn't work all the time. We must try to present visually a broad story, but our own technical limitations produce narrow pictures. In this sense the need for a correspondent is greater than ever in Vietnam. Someone has to point out that what may look like Armageddon, isn't Armageddon . . . visual drama does not always indicate essential meaning. This problem is faced by televisition everywhere; it is heightened in Vietnam.

Fatigue is always a problem, especially for the cameramen, and particularly when they do get to film battle footage. Jim Wilson, a 33-year-old cameraman for CBS News who usually spends several months a year in Vietnam, pointed out :

The Army trains you not to do some of the things we do. You hop out of a chopper first to film the troops getting off. You run back behind them to film where they are going. Often you're exposed to fire. You physically put yourself through more than the troops go through . . . lugging your equipment in 100 degree heat. After awhile you're in no shape to do a decent job.16

The network correspondents who are seen each evening reporting from Vietnam get most of the credit, and few

15 Herford, op. 소.

${ }^{16}$ Albert Kroeger, "Vietnam: Television's Cruelest Test," Television, XXIII (May, 1966), p. 41. 
viewers realize that the unsung people of the war are the men like Jim Wilson who must trudge through the jungles and rice paddies of Vietnam while loaded down with their camera equipment.

Help is on the way for the cameramen, however, since the networks are switching to the new Beckman-Whitley portable sound camera, the CM-16, which was developed in cooperation with $A B C$. It weighs only 15 pounds and goes up to 24 pounds with its power pack and amplifier. Delivery of the CM-16 started in the summer of 1966.

This portable sound equipment now being used is one of the innovations which vietnam has introduced into TV's coverage of warfare. In the days of Korea, the films were made by silent cameras with the sound added later. But the new portable sound cameras have changed all that. The onthe-scene battle sounds can now also be captured by crews in the field.

The climatic effects on all this expensive equipment, however, can be quite serious. The problems are principally those of rust, corrosion, and fungus growth. Therefore, the gear is treated with preparations to combat the effects of water and corrosion. 
The film the networks use, whether color or black and white, is generally kept under refrigeration in Saigon. Because of this, fungus problems with the film are not serious, except on expeditions into the field. Then refrigeration becomes more difficult. A frequent practice at $\mathrm{NBC}$ is to pack the film in dry ice in picnic type, disposable ice boxes in an effort to keep it cool before it is used. 17

These portable sound cameras have greatly increased the impact of television's war coverage. A good example of this fact occurred in March of 1966 at Qui Nhon, on the coastal lowlands of South Vietnam. John Laurence, a 26-yearold CBS newsman, and his camera crew were on a road march with an American unit when suddenly a South Vietnamese armored column opened fire on them, mistaking the Americans for North Vietnamese.

The Danish cameraman hurziedly filmed the armored column's belching guns, the near-by explosions, and then panned to an American officer who was shouting into a

\section{${ }^{17}$ Personal letter from L. A. McClelland, Manager,} Bureau Services, NBC News, New York, dated October 7, 1966. 
telephone: "For God's sake, stop it! We're Americans!"18

The soundman, a 22-year-o1d Thai named Va1lop Rodboon, was then hit in the stomach by shrapnel and toppled over. Laurence turned quickly to interview the wounded member of his crew, while the cameraman continued to capture the whole scene on sound film. But most remarkable of all, Rodboon still operated the sound equipment for his own interview.

Each of the three TV networks have suffered casualties in covering the fighting. Some of the men have been wounded seriously, but as of this writing none of the men employed by the television networks in Vietnam has yet been killed.

But almost all of them have had some close calls. For example, LBS soundman Bob Funk, cameraman Jim Wilson, and reporter Morley Safer were shot down near the Ankhe Pass in a Medevac helicopter. Safer narrated the incident for TV while lying in the brush, with sounds of bullets recorded on the sound track:

The chopper must have taken at least five or six hits. One went past my face, broke the plexiglass and hit, or rather bruised, the arm of our soundman, Bob Funk. We're not exactly pinned down,

18 Hickey, (October 1, 1966), 오. cit., p. 10. 
but somewhere in the woods are a couple of snipers who had enough fire, $g^{\text {ower, anyway, to }}$ bring down this hellcopter. ${ }^{9}$

Officially, all the news media in Vietnam are considered to be non-combatants, and so none of them is expected to carry weapons. Under the rules of war, a civilian caught with a weapon can be treated as a spy. But according to NBC correspondent Wilson Hall, there is a feeling among the TV crews in Vietnam that they are considered fair game by the enemy anyway, and that is why a number of the correspondents and cameramen go armed when they are covering a military operation in the field. 20

There have been a few occasions when men from the television networks have actually joined in the fighting. Larry Travis, a cameraman for NRC, was given a five day film assignment at an outpost near Danang. But within hours after he arrived, his camera broke down. So Travis spent the better part of four days helping with guard duty and lobbing grenades into a half-acre of enemy territory before a helicopter.

19 Martin Tolchin, "Vietnam: The Camera Goes Into Battle," The New York Times, Apr11 17, 1966, Part II, p. 17. ${ }^{20}$ Kroeger, (July, 1965), 오 cit., p. 74. 
finally arrived to pick him up.

Another NBC cameraman, Vo Huynh, a Vietnamese, was with government troops at Dong Xoai who were running out of ammunition one evening. He suggested that the men craw 1 out into the barbed wire defenses and remove the cartridge belts worn by Vietcong who had died in attacking the position. But no one volunteered. So Vo put down his camera and crawled out himself. A little later he returned, covered with mud and blood, but with a dozen enemy cartridge belts. However, the war in Vietnam is more than just a ground action. The Navy and the Air Force also are involved, and the networks have been filming their contributions, too. Since most of the Navy's activity is on ships at sea, it is somewhat of a problem getting television crens out to them. But once on a ship, the crew's problems of capturing the story on film are few, since the action is limited to the confines of the vessel.

Filming strikes by the Air Force, however, is an entirely different matter. To film such an operation becomes a major undertaking, because the action is not limited to a small area. While only one camera is needed to shoot a ground war sequence, many more are required to get a close 
air support story on film.

The usual system has been to place one cameraman in an attacking fighter and a correspondent with a tape recorder in another to provide commentary. A cameraman also generally is placed in the propeller driven "spotter" plane with the Forward Air Controller, who directs the strikes by the fighter aircraft. Then a third cameraman is needed to film ground preparations, taxi-out, take-off, and landing scenes.

A11 cameramen and correspondents, of course, must be briefed on the mission before hand, and for those who will be flying, a dozen other factors are involved: survival if downed in enemy territory, ejection seat procedures, use of the parachute, etc.

In most cases the cameramen are not experienced in flying in high performance fighter aircraft. So it is difficult for them to react to the serere "G-forces" which force their cameras down into their laps at the very moments that should be filmed.

As a result of these difficulties, the TV networks have found that, for the most part, the job of filming the air war effectively for television takes too much effort and prefer to spend their time more profitably in other areas. 
Covering the political conflict. But the war in Vietnam is much more than just a military conflict. It is also being fought on the political front in Saigon and in hundreds of South Vietnamese hamlets. Even though covering the military action is a most difficult and dangerous job, still that part of the conflict in Vietnam can be captured on film. Trying to get a visual treatment of the political situation, however, is an entirely different matter. As Charles Collingwood of CBS pointed out:

People understand the principle of war . . . of death. Television can show them that. But what we find now is that the correspondent has to deal with politically complex issues as well . . . what goes on in people's heads. We've never found a way to put a camera inside people's heads. 21

Every story presents some frustrations, but for the TV crews in Vietnam, trying to cover the political aspects of the war is the biggest frustration of all.

According to David Burrington of $\mathrm{NBC}$ :

There are so many imponderables and ironies here that it's sometimes difficult, if not downright impossible, to explain what's happening

$$
{ }^{21} \text { Kroeger, (May, 1966), 오. c1t., p. } 46 .
$$


in terms that an American audience can understand. 22

CBS correepondent Dan Rather said, "I get a hopeless feeling when I try to get on top of things. It's so manyfaceted that nobody can really be on top of $1 t . " 23$

To take the physical punishment of covering the war in the field usually requires a younger man, but to make sense out of the political complexities generally requires an older, more experienced correspondent. This presents the TV reporter in Vietnam with the dilemma of needing the stamina of youth along with the wisdom of age, an anomalous combination.

Fifty-one-year-old Peter Kalischer, CBS Far East Correspondent stationed in Tokyo, explained:

We're reluctant to let a young correspondent do a stand-up, look-in-the-eye piece on some aspect of Vietnamese politics, and to try to make some sense out of it for an American audience. I consider it very dangerous to try. I'm supposed to be the grand old man around here, and I'm reluctant to do it myself. Short-range political

${ }^{22}$ Hickey, (October 1, 1966), ㅇ․ ․ㅗ., p. 8.
23 "Covering Vietnam: Crud, Fret, and Jeers," Time, LXXXVII (June 10, 1966), p. 54. 
prognostication in Vietnam is very, very risky. 24

As a result the responsibility for solid background reporting is being left to the occasional visits of men like Eric Sevareid of CBS, Howard $\mathrm{K}$. Smith of $A B C$, and $N B C$ 's Chet Huntley; and to Asian regulars 1ike Kalischer and Murray Fromson of CBS, ABC's Lou Cioffi and Sam Jaffe, and NBC's John Rich. These latter men usually come to Vietnam on short-term assignment from their watch-posts in Bangkok, Hong Kong, or Tokyo.

But for those TV newsmen who stay on in Vietnam month after month, just getting a lead on a breaking story is a real problem, since vietnam is a country where reliable sources of any kind are all but nonexistent. NBC's Ron Steinman explained:

It's a constant game of nerves; you try to deploy your available forces to the best advantage. Each network bureau chief has his own set of confidential contacts in Saigon who he hopes will tip him off to the next big. . .
civil demonstration. 25

${ }^{24}$ Nei1 Hickey, "Vietnam: Is Television Giving Us the Picture?", IV Guide, XIV (October 15, 1966), p. 17. ${ }^{25}$ Hickey, (October 8, 1966), 오. 소. , p. 27. 
Tips for stories come in a number of ways. At least one network has a paid informer in the office of Premier $\mathrm{Ky}$, South Vietnam's chief of state. ${ }^{26}$ But usually leads on oreaking, nonmilitary news comes from friends and relatives of Vietnamese employed by the networks. Still, chasing down stories in Saigon becomes so exasperating that a chance to go into the field often becomes a welcome relief. Covering the political situation in Saigon, or any place else in Vietnam poses other problems. Again, Peter Kalischer of CBS:

A tipster calls and says such-and-such a high school is going out. Depending on the mood of the rioters, the cameraman and I get right in the melee and film close-ups. If for some reason they don't want to be filmed, we have to do the story on the run, dodging behind trees and cars.

You're faced with the question do you stand with the police and become the target of rioters throwing rocks, or with the demonstrators and get tear gas, or in the middle and get both? That's one
of the problems we have covering for television.

But battles remain at the hard core of network television's Vietnam coverage. An unidentified correspondent

$$
\begin{aligned}
& { }^{26} \text { Ibid., p. } 28 . \\
& { }^{27} \text { Kroeger, (July, 1965), 으. cit., p. } 72 .
\end{aligned}
$$


told Neil Hickey of IV Guide:

New York will send us a cable saying, 'Need more background stories on politicai and social angles.' So we film pieces on the inflation in Saigon, on the rice harvest, or the black market. Then New York cables back: 'Your pieces on inflation excellent. However we note that $X$ had a terrific Marine battle near Danang.' The only way you can get a blast from New York is to get beaten by the opposition on a combat story. 28

Letters from Vietnam. The preceding two sections of this chapter were intended to give some idea of how the war in Vietnam is covered by network television and of the difficulties that are involved. But for a more graphic description of the newsman's problems in Vietnam, the following excerpts are offered from two letters written by TV men on the scene.

Jesse Zousmer, ABC vice president and director of TV news, toured Vietnam early in 1966 on a fact-finding tour, while looking for future coverage possibilities. On March 4, as he and his wife were returning home, both were killed when their Canadian jet crashed near Tokyo. Thus Zousmer became an indirect casualty of vietnam.

$$
{ }^{28} \text { Hickey, (October 8, 1966), op. cit., p. } 31 \text {. }
$$


A few weeks before his death, he wrote a letter from Saigon to ABC News President Elmer Lower and told what covering Vietnam is like for the men who are stationed there. Zousmer said:

. . the problem of covering the war . . . if I can float words off a paragraph . . . is like trying to cover our South in revolt on a bicycle with one correspondent; it's like trying to keep on top of the news if each of our states were producing the top news story of the day. It's like (as actually happened to us) being 13 miles from the biggest battle in Vietnam of the day not to hear a word of it, even though I talked to such as Westmoreland, Kinnard, the Air Cav commander, and more damn PIO's (public information officers) than you could smile at. They didn't know either. The press corps in Saigon didn't know until the next day's briefing. 29

For Ron Nesson of NBC, like many of the network

correspondents in Vietnam, totai coverage of this confusing, frustrating war isn't too satisfactory, and certainly not what he would like for it to be. In a letter to NBC Executive Producer Robert Northshield, Nesson wrote:

I only wish I were as happy with Vietnam coverage as you are. Every week I look at the kines of Huntley-Brinkley, Cronkite, and Jennings, and every week I realize that one roll of $\mathrm{film}$ is just about the total picture of the Vietnam war

${ }^{29}$ Kroeger, (May, 1966), op. cit., p. 42. 
for millions of people. Yet the week portrayed on the film never matches the week as I lived it and felt it and reacted to it.

Sure, some of what's missing can be blamed on difficult transportation, mechanical problems, personnel shortages (and short-comings), the here-today-gone-tomorrow pattern of fighting. But there is something more fundamental than that preventing us from showing viewers what Vietnam feels like. When I first came here I thought my job was to make a mosaic. . . each story filling in a little of the picture, so after enough stories the picture would 38 coniplete. That theory doesn't seem to work. ${ }^{30}$

Sometime later Nesson was wounded while on an operation in the Central Highlands of South Vietnam. He was struck in the chest by a grenade fragment, underwent surgery at a field hospital, and was transferred back to the States for recovery.

\section{THE MEN WHO COVER THE WAR}

Covering a war has never been easy, but in vietnam the multi-dimensional nature of the struggle makes it even more difficult. As previously indicated, these problems weigh more heavily on the TV newsman in Vietnam than on his colleagues in the other media. So why go to Vietnam as a

$$
{ }^{30} \text { Ibid., p. } 38 .
$$


television newsmra? The reasons are many. But at the top of the list for the TV reporter in Vietnam is the fact that theirs is the hottest beat in the business.

For the newsman, covering warfare has always provided a certain degree of exhilaration, but in the case of Vietnam, there is the continuously compeling pull of a first-rank story in desperate need of top-rate reporting. And with the TV newsman, there is also the appeal to his pioneering spirit, since Vietnam is really the first war ever covered by television.

The network men in Vietnam are all volunteers; none is sent there against his will. The pay is the same as for other TV newsmen stationed overseas and no network pays combat bonuses.

But there are tangible rewards. Some of TV's people in Vietnam are undoubtedly aiming for the personal glory and the big payoff that awaits those whose reputations are made in the jungles. One of the younger correspondents told TV Guide's Neil Hickey:

Let's be truthful. We're all war profiteers. We know that if we prove ourselves here we can short-cut our careers by five or ten years. Here in Vietnam you can get your face on the 
network news three or four times a week. That's
more than you can do in the United States.

Then there is the matter of experience. Garrick Utley of NBC pointed out, "You get more experience out there in two months than in two years anywhere else, whether as a soldier or a journalist." 32

How many are there. As noted in the opening chapter, the three networks have just over eighty accredited journalists in vietnam. CBS and $N B C$ are usually said to have the largest staffs on the scene, followed by $A B C$. These generally range from 20 to 30 people.

Are these staffs big enough to adequateiy cover the war? There seems to be no general agreement on this question. For example, Peter Herford, the Saigon bureau chief for CBS, said that practically speaking he does have enough reporters to cover the story, although stories are still missed. But he felt that no matter how many reporters were available, this would still be the case. However, he concluded, "'Adequate' coverage would, no matter whose definition I were to

$$
\begin{aligned}
& \text { 31 Hickey, (October 1, 1966), 요, c1t., p. } 10 . \\
& { }^{32} \text { Tolchin, 오. 도., p. } 17 .
\end{aligned}
$$


accept, be wholly inadequate in covering this war."33

Ron Steinman, head of the NBC bureau in Saigon, implied that he could always use more men in covering the war. But he added, "It is getting the story that is not so obvious, and sometimes letting the obvious one go by that determines if you have enough men to cover the story." 34

As already noted, these Vietnam staffs are also supplemented by the constant flow of commentators from the United States who may spend from a week to a month on special coverage or for familiarization. When material for a special program is being gathered, the network may send an entire crew to Vietnam just to shoot film and gather information for the one program.

Qualifications. But the day-to-day responsibility for covering this story for the American viewer falls on the men who are assigned there.

In searching for the qualifications that the TV networks look for in their Vietnam correspondents, the researcher

33 Herford, op. cit.

${ }^{34}$ Steinman, 오. 소. 
wrote a letter of inquiry to the president of the news department at each of the networks.

William McAndrew, President of NBC News, said that his network looks for men who have a broad and prolonged experience in all the basics of news, combined with a knowledge of the technical and editorial problems of broadcasting:

Preferably, but not mandatorially, they must have a knowledge of French, previous military experience, and previous service in the Far East. Actually, several of the men we have used there covered the Korean conflict, three of them had one year scholarships at Columbia University on Asian affairs, and with about two exceptions they have had extended service as foreign correspondents elsewhere. As it has worked out most of them have had experience in covering beats in Washington, and their ages average nearer 40 than 30 years. 35

In his reply CBS News President Richard Salant indicated that CBS assigns all of its correspondents at one time or another to Vietnam and plans to continue this policy.

Specifically, the qualifications which our men must meet to report from Saigon are precisely the same as the qualifications they must meet to become correspondents for CBS News -- they must

${ }^{35}$ Personal letter from William R. McAndrew, President of NBC News, dated October 5, 1966. 
be and are first-rate journalists who can observe we11, who can report what they see, and can explain the significance of what they see. 36

There was no reply from $A B C$ News.

Lack of experienced personne1. A11 three networks are having trouble in getting seasoned and knowledgeable men for Vietnam. This is mostly because of the necessity for the correspondents to live as soldiers, with all of the dangers and discomforts of military service. Since TV newsmen and technicians are generally not responding in sufficient numbers, this has created great opportunities for the young and ambitious.

The problem of securing enough cameramen and soundmen is especially acute. These highly trained men in the States are usually too old for jungle marches in 130 degree heat and are generally too affluent to want to bother with such discomforts .

As a result, technicians from parts of the world other than the U.S. are often hired. This is especially true In regard to the cameramen, a number of whom are from South-

${ }^{36}$ Personal letter from Richard Salant, President of CBS News, dated October 12, 1966. 
east Asian countries where there is no television. Because of this a curious anomaly exists: some of them have never seen TV or their own film which is viewed dally in the American home.

News management. Generally speaking the TV correspondents in Vietnam, regardless of their level of experience, are on their own in deciding what to cover and what to say. This is because the fighting there is a shifting thing, and so one never knows where to start from one day to another. Then, too, the cables back to the States can sometimes take 10 or 12 hours each way. Therefore, it is possible for 24 hours to elapse between the time a question is asked and a reply is received.

In answering the researcher's question about news management, Ron Steinman, NBC bureau chief in Saigon, wrote he is sometimes given instructions on what to cover, fust as any editor is. But he said that he is never told what to say. Rather, he instructs his reporters to so present their stories that the facts will tell the story and allow the viewer to make up his own mind. 37

$$
{ }^{37} \text { Steinman, o․ iㅗ. }
$$


Steinman's counterpart for CBS, Peter Herford, also said that there was no news management from New York. He added "if our editors and executives... had a hard line on this war that they could try to impose, they would not be editors and executives; they would be government policy makers." 38

Rest and recreation. The working day for the television newsman in Vietnam usually exceeds twelve hours, seven days a week. In addition to the difficulties already mentioned, Herford noted one other:

. . the problem of coming from a highly sophisticated society where life expectancy has risen beyond 70 years to a part of the world where expectancy is limited to 35 years. Couple with this the need for mature judgement on the part of correspondents and reporters, and the pressure becomes enormous. 39

As a result of this, many of the TV newsmen who have been in Vietnam for awhile suffer from a peculiar form of Asian distemper. To counteract this all three TV networks have compulsory rest and recreation programs which provide

\footnotetext{
${ }^{38}$ Herford, 오. 스t.

${ }^{39}$ Herford, op. cit.
} 
for a regular rotation of personnel. The idea is to give the bureau members regular periods of rest in such near-by places as Hong Kong, Taipei, Singapore, Bangkok, or Manila. It is felt that such a program helps morale and also tends to lessen the numbing effect of the Vietnam work load, which seems to erode the resources of even the best of the television newsmen.

In addition to these frequent periods of rest and recreation outside the war zone, each network has the same policy of keeping the tours of duty in Vietnam relatively short. Normally each tour lasts about one year.

The cost. The expense for maintaining these television reporters in Vietnam is immense. NBC News President William McAndrew said that NBC spent about $\$ 750,000$ on direct Vietnam coverage in 1965 and that it could go to one million dollars in 1966. Although CBS has not made public the cost of its coverage of Vietnam, its figures should rival those of $\mathrm{NBC}$. The cost of $\mathrm{ABC}$ 's coverage runs at $\$ 60,000$ to $\$ 75,000$ a month, and this figure would also approach those of the other two networks. 40

40 Kroeger, (May, 1966), ㅇ․ 도., p. 38. 
Incidentally, the networks generally are not able to get a financial return for all this expense and effort of covering the war. But it causes little worry, since the networks have never really expected to "sell" their vietnam product anyway. This coverage, like most TV news, generally amounts to public service. ${ }^{41}$ But at stake is that all important and elusive thing called network prestige.

\section{GETTING THE FILM HOME}

For the television network, prestige becomes a hollow word if after all this trouble and expense the story on film from Vietnam can not reach the States in $t$ ime to beat the competition. Saigon is 12,800 air miles to the west and a 13 hour time differential from New York. As a result, just getting the exposed film back to the U.S. In reasonable time becomes a real battle in itself. This calls for ingenuity, a mind for detail, and an ability to cope with incessant frustration. But amazingly, with everything working right,

${ }^{41}$ Notes taken from audio tape, "Television War Correspondent: The New Breed," a seminar of the New York Chapter of the National Academy of Television Arts and Sciences, New York Hilton Hotel, March 23, 1966. 
film can be shot, shipped to the States, and broadcast all in the same day.

Saigon's airport has become the busiest in the world. 3o getting film out of the South Vietnamese capital is not a problem, as the city is well stocked with commercial air lines and the government's Military Air Transport Service. Therefore, much of the film aimed at America's 70,000,000 TV sets is flown out of Saigon.

This presents the possibility that mid-morning footage shot there has a chance of being broadcast the same evening in the U.S. For instance, when the American embassy was bombed by terrorists on March 30, 1965, NBC had film from the scene by 11:30 a.m. Vietnam time. It was hurried onto a military plane for Guam and Hawail and then trans-shipped to Los Angeles. Upon reaching the States, the film was processed and edited and was fed into the $11 \mathrm{p} . \mathrm{m}$. EST news circuit to NBC affiliates.

However, this is generally not possible for film that is shot in the interior of Vietnam, since it always takes a while to get such footage to Saigon's airport. In these cases military aircraft must usually be depended upon to get the film out of the interior of the country. 
Film is sent back to the U.S. on whichever plane arrives first in either Seatt1e, San Franc1sco, Los Angeles, or New York. It can come via Tokyo, Hong Kong, Bangkok, Manila, Honolulu, or even around the other way, through Paris.

Most of this film from Vietnam arrives in New York or on the West Coast in raw and unedited form. Frequent ly, it is also with a "wild track," or sound on a tape which the editor must bring into rough sync with the film. It's tricky business, and especially when the material must be swiftly handled to meet a deadline.

Time is always the big factor. NBC even has what it calls a "crash unit" at Kennedy International Airport in New York to meet and handle incoming shipments from Vietnam. The goal is usually to get the film on each network's early evening newscast, the major news slot of the day. But for the editor in New York, there are times when even having the film available presents a problem. Maybe the Vietnam film is not too newsworthy after all in view of other world happenings on that day. But the expense of flying film from Vietnam, of developing it on the West Coast, and then of leasing a line for $\$ 3,000$ to transmit it to New York so it 
can be included in a newscast can have an overbearing effect on news judgement. The film may literally price itself into a program.

But according to Television Age magazine, of all the footage from Vietnam that is sent to the U.S., only about two per cent of it gets on the air in a month's time. 42 As a result, a few correspondents have complained that some of their best pieces are never used.*

How the film is used. When the film does get back to the States, and if it is used, the coverage falls mainly into the early evening news shows of the three networks: ABC's "Peter Jennings with the News"; the "CBS Evening News" with Walter Cronkite; and NBC's "Huntley-Brinkley Report." These news programs on CES and NBC are both 30 minutes in length. At the present time, the $A B C$ show is 15 minutes long, but is scheduled to go to a half hour in January of 1966 , p. 70.

42"Camera in Combat," Television Age, XIII (March 14,

*A "typical" sequence of the involved process of getting film from Vietnam back to the States in time for an evening newscast is included in Appendix A, under the title of "The Impossible Takes 20 Hours," on p. 139. 
1967, expressly to provide more time for covering develop* ments in Vietnam.

Even on a half-hour news program, however, the Vietnam war story for the day must be presented in segments of not more chan three to four minutes, and often less. As CBS correspondent Charles Collingwood pointed out, "It's a problem to get interpretation, objectivity, completeness, and balance in the short time of a night's news program."43 To help overcome this difficulty, ABC switched its public affairs series called "Scope" to a war footing at the beginning of 1966, going from a broad range of subjects to strictly Vietnam and related features. The title has now been changed to "ABC Scope: The Vietnam War." With Howard K. Smith as the anchorman, the show has studied such phases of the war as the dissent movement, the draft, and the war's effect on families of GI's back in the States. Of course, much time is also devoted to battlefield coverage.

In April, 1966, NBC launched its "Vietnam Weekly Review" with Garrick Utley as the anchorman. The purpose

${ }^{43}$ Kroeger, (May, 1966), op. cit., p. 46. 
of this show is to reach beyond the day-to-day coverage and to provide an overflow and analysis of all major political, diplomatic, and military developments in the conflict. Some of the questions which this series has been considering on a regular basis are these: What are the attitudes of our nation's press toward the war? How is our Vietnam policy affecting relations with other countries? And which way are the currents of opinion drifting in Washington? The show also summarizes changes in the U.S. military position at the end of each week.

In addition, each weekday morning NBC presents "Vietnam Report" on the "Today" program at 8:09 a.m. According to $\mathrm{NBC}$, on all of these regularly scheduled news shows, it is averaging about two hours a seek on Vietnam coverage. 44

But a problem of shows like "Scope" and "Vietnam Weekly Review" is that viewers just do not seem to sit through programs such as these, and as a result they generally have very low audience ratings. Also network affiliates often are reluctant to clear them. "Scope," for example, is carried by fewer than one hundred stations, although the number

${ }^{44}$ Ibid. , p. 38. 
is up a little since the program switched exclusively to covering Vietnam. It was originally offered to more than $150 \mathrm{ABC}$ affiliates.

At CBS, News President Richard Salent said that his network does not plan on such a Vietnam week-end wrap-up show of its own. "We want to get Vietnam into our regular news shows, as we've been doing. Sunday isn't the place for it. Everybody is out." 45

of course, each network also schedules numerous specials and panel discuseion programs which focus on Vietnam. So altogether, a considerable amount of Vietnam fare is presented each week by the three networks. But unfortunately, many of these programs that lend perspective to the networks' coverage of the war are rarely seen by the great majority of the American television audience. According to the ratings, which are generally quite low for such programming, few people are willing to sit through an hour's worth on Vietnam, preferring entertainment shows instead.

${ }^{45}$ Ibid., p. 41. 
Summary. As pointed out in the preceding pages, covering the war in Vietnam presents many problems for the three television networks, and the biggest one of all is in trying to make sense out of the political morass there. Some of the biggest battles of the war are fought not in the jungles, but in the minds of American and Vietnamese officials, and as such, these battles cannot be filmed. Therefore, television, as a picture medium, is handicapped in its artempts to cover the political story in Vietnam.

Although covering the political situation is the biggest frustration for the networks' men in Vietnam, there are other difficulties which influence their ability to cover the fighting, which remains at the hard core of TV's Vietnam reporting. Because of the guerrilla nature of the war, there are few set battles, and the fighting takes place at scores of places across the country at the same time. This presents many transportation headaches as the networke try to get to the scene of the action, and as a result getting good battle footage on film is mostly a matter of luck. Therefore, the biggest obstacle in covering the military side of the story is one of logistics. 
But network newsmen still volunteer to go to Vietnam. First, because the war is the top story presently in the news. Also, it is the first war ever covered by television, and by being there, they are helping to blaze a new trail in the history of electronic journalism. Another reason, of course, is for the personal advancement that w111 come for those whose reputations are made while covering the conflict. Still, the network executives back in the States are having a difficult time in getting enough good men to cover the war because of the many dangers and discomforts which the television newsman must face while working there.

One final problem which the reader should not overlook is that of getting the film, which has been shot at so much expense and effort, back to the States in time for a particular program, usually an evening newscast. This is a daily headache, and it is ironic that after the news staffs go through so much in Vietnam to get a story on film, that story still might not get back in time to be newsworthy. 


\section{CHAPTER III}

\section{CENSORSHIP AND PRESS RELATIONS}

War and censorship have gone hand-and-hand in the conflicts of the recent past in which the United States has been involved. For instance, during World War II American correspondents even wore uniforms and were considered part of the military "team." As such, they also made their own kind of contribution in helping to win the war.

But for better or worse, that situation does not exist in Vietnam. There is no formal censorship of outgoing news. Reporters can roam almost anywhere they wish and are free to make their reports without the advice or consent of any American or Vietnanese official.

However, many newsmen in Vietnam still feel that decisions made in Washington have been hindering their efforts to get all the facts needed for honest and thorough coverage of the story. Therefore, another problem that Vietnam presents for the news media is one related to censorship and press relations between the media and government-military authorities . 
The news-coverage difficulties from this problem weigh equally on all the media. But a survey of network television coverage of the war in Vietnam would not be complete unless some space were devoted to how censorship and press relations influence the networks' ability to cover the war.

Restrictions. Although there is no formal censorship in Vietnam, the networks have been asked to cooperate in a number of voluntary restrictions, mostly for reasons of military security. For example, as a condition of covering major military operations from the outset, the networks voluntarily have agreed to withhold the use of their film unt1l the operation is publicly announced.

The networks also cooperate with the Defense Department in reporting casualty statistics. On a daily basis this is done only in general terms, using the words "11ght," "moderate," or "heavy." In addition, the networks have agreed to avoid the premature public release of photography of military casualties before the next of kin are notified. Accordingly, the TV networks hold film which would identify a military casualty until official notification can be made to 
the next of kin.

Certain other restrictions are placed on the networks. In general terms, these apply to a few classified weapons that are employed in Vietnam and access to some air bases. More specifically, the air war over North Vietnam always is restricted, because every available seat is needed for a trained airman who will contribute to the mission in a highly dangerous area.

Because the air raids above the 17 th Parallel are restricted to military photography only, the networks have to take what they are given concerning that part of the war, and this can present some problems. One example occurred on June 29,1966 , with the first bombing by U.S. planes of the oil storage facilities in and around the North Vietnamese industrial centers of Hanoi and Haiphong. Still pictures of that raid were made available to the magazines and newspapers, but no film was released to the networiks. NBC and CBS protested to the Defense Department, but without success. However, on July 6, Walter Cronkite's evening news did include film of the raids, supplied by a Japanese news film agency with contacts in North Vietnam. 
Why wasn't the U.S. military film of the raids released? The answer was not given publicly by an official spokesman, but TV executives felt it was because of the Pentagon's fear of the psychological effects that the film of the bombings could have on American viewers.

But generally the voluntary cooperation from the networks on matters of military security seems to be working rather well. At least, the Pentagon says it is. Arthur Sylvester, Assistant Secretary of Defense for Public Affairs, told a forum of the New York Chapter of the National Academy of Television Arts and Sciences that in most cases the Defense Department has had tremendous cooperation from the networks on matters of security. On the whole, he said he would salute them for the job they are doing of protecting sensitive information. But still he noted that the majority of the letters at the Defense Department are from people who feel that too much news is given out which is helpful to our enemies. 46

${ }^{46}$ Notes taken from audio tape, "Television War Correspondent: The New Breed," March 23, 1966, 오. 소. 
Press relations. Generally, the TV veterans have unanimous praise for the cooperation available at every level in the combat areas. But the prevalent attitude toward the armed forces' public information set-up in Saigon is a different matter.

Every afternoon in Saigon the U.S. Military Command, Vietnam, or MACV, holds a five o'clock briefing for the press. According to government spokesmen, a policy of "total disclosure" is followed. But many in the TV corps feel that the briefings are less than total when battles are going badly or the Saigon political situation becomes sticky.

In regard to this, NBC's Garrick Utley said:

There is an unofficial censorship rampant which takes the form of officials not commenting or informing on various military and political matters, or simply professing ignorance on something they do know.

The worst problem is that most of the important news on the war comes through just one channel, and it is usually impossible to check its authenticity. 47

\footnotetext{
47 Jean Greenwa1d, "TV Newsmen Caught in 'Asian Hurricane'," Editor and Publisher, XCVIII (July 24, 1965), p. 38.
} 
Hanson W. Baldwin, military writer for The New York Times, noted that often correspondents returning from the field found that they knew more than the information officer. As a result, he might be unable to reply effectively to some of the loaded questions from the press, and without meaning to, he could, therefore, give the impression of withholding information. 48

But at any rate, the dally briefings in Saigon have become known among the press corps as the "five o'clock follies." To these briefings can generally be traced what has been described as the "credibility gap," or a lack of belief by far too many newsmen in the government's word. Much of this is a carry-over from the Ngo Dinh Diem regime and the period after when the press was often misled and even lied to by both Vietnamese and American officials. ${ }^{49}$

Also some newsmen have noted that government attitudes toward the press, as reflected in the Saigon briefings, are not constant and tend to fluctuate. For example, Charles

\section{Baldwin, 오. cit., p. 30 .}

${ }^{49}$ Neil Hickey, "Vietnam: Is Television Giving Us the Picture?", TV Guide, XIV (October 22, 1966), p. 36. 
Arnot of $A B C$, a regular in Vietnam since 1962 , said that he had seen four phases of government attitudes toward newsmen. In 1963, he felt it was concealment, with the U.S. military and the Vietnamese government highly sensitive to adverse criticism. Then a reveal policy was adopted when it was felt that the American people should be made to understand that the war could last indefinitely. Arnot said that a conceal policy was again in effect when U.S. planes in February of 1965 began bombing North Vietnam, because loose information then might have compromised military security. But Arnot believed that by the spring of 1965 another period of reveal was in effect. 50 But this lack of a constant attitude toward the press is another reason for the difficulties in relations between the government and media.

It is not surprising then, that a number of television newsmen feel it has been the U.S. government which has made the job of explaining the war in Vietnam so difficult. Walter Cronkite of CBS has suggested that one of the reasons for the great confusion which plagues the U.S. today over

$$
\text { 50 Kroeger, (July, 1965), 오. c1t., p. } 72 .
$$


Vietnam is the fact that we were committed without a proper airing of all the facts. 51

Lou Cioffi, ABC Far East correspondent, said:

The main fault of the inadequate reporting of the Vietnam situation lies with Washington and its failure to explain to the American people and to the world what is happening in Vietnam, and what we propose to do. We cannot talk about pacification and negotiation at the same time . . If our government is not sure what it intends on doing, how can the press be blamed for faulty reporting? 52

Press relations also have suffered in Vietnam from several other factors. In February, 1965, when the U.S. started bombing North Vietnam, a news concealment dispute centered on the Danang airbase, which was virtually closed to the press for a time. During the first days of the air strikes above the 17 th Para1le1, correspondents were allowed to talk freely with U.S. pilots about their missions. But then the pressure began to build up for reasons of security. Eventually, the mess halls and even the officers' club were closed to newsmen. The news blackout turned into a we11-

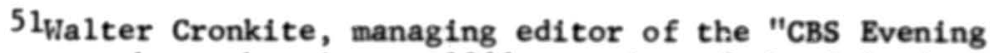
News," a speech to the winter, 1966, meeting of the Inland Daily Press Association.

${ }^{52}$ Kroeger, (May, 1966), ㅇ․ it., p. 46. 
reported story of its own, since the media felt the military was concealing news. It finally blew over, but the strain that exists between the news managers and the news gatherers in Vietnam is ever present.

Other complaints have come from the sometime practice of providing each correspondent with an escort. Many reporters felt this practice was not aimed at security matters, but rather at controlling what American fighting men might say.

A11 newsmen in Vietnam also must get accreditation from the Saigon government, which requires a pledge not to make derogatory remarks about the South Vietnamese government. But apparently, this is only a vestige of the Diem regime and is now just a formality. Still, many newsmen feel that a tacit threat of withdrawing their news accreditation does exist. But so far it has not been used against any TV newsmen.

Additionaliy, the relations between the government and the press are a serious matter, because, as already noted, without military help, the TV networks would have great difficulty in covering the war at all. Most battle footage would be missed if the networks could not count on military 
transportation into the areas where the fighting takes place.

But although tensions do exist in the press relations in Vietnam, there is actually little that the media need to fear, because the rivalry among the armed services for news coverage is intense; especially do they seek television exposure.

NBC's Jack Fern pointed out:

The arts of public relations, packaging, publicity, and image-building have all grown up in the last 20 years . . . and now for the first time, they're being applied to war; there are unnumbered people here whose sole job is to put the American military efforts, no matter how grisly, in a good 1ight. The number of PIO's in Vietnam is fantastic, all cranking out a party line, or trying to get their unit its share of publicity. 53

Peter Herford of CBS commented:

One can't argue with the natural tendency of PIO's to make their particular service look good, and to get as much good publicity for it as possible. But it's detracting from their main mission, which is to inform the press about the military situation. There are too many flacks and not enough information officers. 54

53 Hickey, (October 22, 1966), ㅇ․ c1t., p. 37.

${ }^{54}$ Hickey, (October 8, 1966), ㅇ․ 다., p. 30. 
More recently, the chief complaints of the Saigon press corps have been attached to reported statements of Assistant Defense Secretary Arthur Sylvester that newsmen should "get on the team," and perhaps even be the "handmaidens of government" in a united front before the American people and the world. As a result, Neil Hickey of IV Guide, felt many newsmen have gone out of their way to establish their independence, and some have overreacted to what they perceive to be Sylvester's desire for a laundered reporting of the war. 55

However, the researcher could not help but note that during a question and answer period at the New York seminar on the "Television War Correspondent," Sylvester said he did not think TV should do anything for the government. He also stressed he does not advocate anyone following the government line. ${ }^{56}$ It would seem, therefore, that part of the problem that exists as far as press relations are concerned is one of misunderstanding or of misquoting. And Mr. Sylvester is

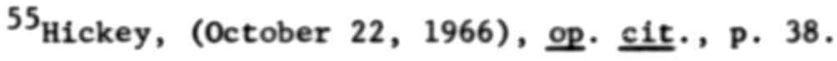

${ }^{56}$ Notes taken from audio tape, "Television War Correspondent: The New Breed," op. cit. 
offered as the best example.

But regardless of what government officials actually say, the press corps in Vietnam is determined to report the war as completely as possible. As NBC's Jack Fern said, "My job is not to put anybody in a good 1ight. I'm not a flack for any group. My responsibility is to the American public, or to some private theory of truth."157

Robert Northshield, executive producer of NBC News, probably summed up the feeling of most newsmen when he concluded:

The cream of American youth is getting killed in Vietnam. And the Administration, the Pentagon, are feeling it. They're afraid that the American public will change its mind about our Vietnam commitment.

When we are accused of lack of patriotism, it's not so. We are American citizens talking to the American people, and I personally am in support of our vietnam efforts. But the ggyernment has a vested interest . . . we don' $t .58$

$$
\begin{aligned}
& { }^{57} \text { Hickey, (October 22, 1966), ㅇ․ 서., p. } 37 . \\
& { }^{58}{ }_{\text {Kroeger, (May, 1966), ㅇ․ 다. , p. } 26 .}
\end{aligned}
$$


Summary. Although no formal censorship exists in Vietnam, there are a number of voluntary restrictions that are placed on the news media, and the television networks have agreed to accept them. As a result, the networks withhold film of any military operation until it has been publicly announced. Secondly, they have agreed to give daily casualty figures only in general terms, avoiding specific numbers. Finally, it is the policy of the networks to follow the Pentagon's request by not releasing films or pictures of military casualties until the next of kin have been notified. Generally the Defense Department has been pleased with the cooperation it has received from the networks in this regard.

But for the news media, a bigger problem is in the area of press relations. This has been the cause of much complaint from the press, especially the military's public information setup in Saigon. There is a general feeling that the government has not always been honest with the press, and this has resulted in what has been called a "credibility gap," or a lack of belief by many of the press corps in the government's word. It is not surprising then that so many television newsmen place the blame for what they feel to be the inadequate reporting of this conflict on the government. 
The relations between the press and the news media are particularly important to television, because if poor relations should eliminate some of the help that the military provides the networks, especially in transporting their heavy equipment, TV's men would hardly be able to cover the military side of the conflict at all.

Censorship and press relations are also to be taken seriously, because if a newsman does not follow the voluntary restrictions in Vietnam, he could lose his accreditation to cover the war. But so far this has not been used against any of the network newsmen.

Individually, there may be some reason for concern about loss of accreditation. But collectively, the television networks have little need to fear about a sudden lack of cooperation from the military in helping to cover the war brought on by some future press relations dispute. TV tells the military story in Vietnam to more people back home than any other medium, and the various services are eager to maintain this coverage by television.

It is the conclusion of the researcher that at least some of the difficulties in press relations brought on by 
the war in Vietnam are the result of misunderstandings between the media and government, but particularly from the misquoting of a few government officials. 


\section{CHAPTER IV}

\section{EXAMPLES OF WHAT THE VIEWER CAN SEE}

So far this study has been devoted mostly to the problems that network TV faces in trying to cover the war in Vietnam for the $70,000,000$ television sets in the U.S. But what kind of a story comes out of those screens? The purpose of this chapter is an attempt to answer that question. It would be impossible for the researcher to see all that network TV has presented on the war in Vietnam and then to pick the best examples of what was produced. But as the research for this project progressed, a number of examples of the networks' Vietnam product were studied. From these the following were taken to give an idea of what is presented for the American audience. These examples are not necessarily the best nor the worst--and, certainly, not all--of the networks' Vietnam efforts. But they are regarded as representative of the Vietnam programming of the three networks. The following also were selected in hopes of giving an idea of the effort that sometimes goes into getting a single Vietnam story for network TV and of the impact that these stories 
can have.

Chopper warfare. One of the earliest specials on the war in Vietnam was produced by ABC in the spring of 1964 and shown late that summer on a series called "The Daring American." The program was called "Letters From Vietnam." But unlike many war films, it was not a set of disconnected battle scenes. Cameraman Drew Mills and producer Gregory Shuker knew that they could not capture the whole picture of the fighting in Vietnam. So they decided to focus on only one aspect of $\mathrm{it}$, the role of the helicopter.

For three weeks during March and April of 1964, Shuker and Mills went on more than 50 helicopter missions. They worked with hand-held cameras, cameras mounted in cockpits, and cameras mounted outside the "choppers" to record every bit of ection possible. The results of all this shooting were some 38,000 feet of $\mathrm{film}$, or almost 19 hours worth, which was then edited down into a tight 52 minutes for showing over the network.

The program did not pretend to examine the war in depth, but it vividly showed the dangers that are faced by the helicopter crews in vietnam. For example, on one of the 
rocket runs that was filmed, Communist ground fire exploded a rocket that was still in the helicopter's launching pod. The blast burned a patch of hair off Mills' head, burned one of the pilot's eyes, and seriously wounded the door gunner. The chaos of the moment was captured on film, because a camera was fastened to an instrument panel and focused on the pilot's face.

For most viewers, actuality scenes such as these are an unforgetable experience. And it is in examples such as this that television reaches its full potential.

The burning of Cam Ne. The "CBS Evening News" on August 5, 1965, carried a film report by correspondent Morley Safer which represented most of what is best and most of what is distressing about TV's coverage of the war. Few of the networks' reports from Vietnam ever had so much impact, especially in government.

Safer's filmed story showed U.S. Marines using cigarette lighters to burn down Cam Ne, a village which military spokesmen said was fortified and from which Marines had come under Vietcong fire. But Safer didn't see it that way as he stood before the camera: 
The day's operation burned down 150 houses, wounded three women, killed one baby, wounded one Marine, and netted four prisoners. These were old men who could not answer questions put to them in English, and who had no láea what an I.D. card was.

In Vietnam, like everywhere else in Asia, property, a home, is everything. A man lives with his family on ancestral ground. His parents are buried near-by. Their spirits are part of his holdings. If there were Vietcong in the hamlet, they were long gone. The women and old men who remained will never forget that August afternoon. ${ }^{59}$

Speaking later about the incident, Fred Friendly, who at that time was President of CBS News, said that he knew he had some "pretty rough stuff" when the film came in. So after CBS decided to run 1t, the Pentagon was called for anything it might want to add. But the military reaction was that this was the face of war, and so these things are bound to happen. Even so, Friendly said he knew that because of the tremendous impact of television, there would be a nationwide aftermath. 60

The Cam Ne story went on the air, and there was, indeed, an aftermath: CBS was inundated with mail. Friendly

$$
\begin{aligned}
& { }^{59} \text { Tolchin, ㅇ․ 서., p. } 17 . \\
& { }^{60} \text { Kroeger, (May, 1966), ㅇ․ 소., p. } 44 .
\end{aligned}
$$


continued:

I found myself days later under the fingers of two of the highest men in government, being lectured about 'Did I not think what was right for the United States?' My answer . . . was that I didn't always know what was right for the United States but that if truth was not right, wherever we found it with our cameras and our microphones, then there must be something wrong with our country or our story.

But according to Television magazine, public reaction to the Safer report led the Pentagon to ban further such military operations as the burning of Cam Ne. ${ }^{62}$

Still, this one film report which lasted but a matter of minutes points out the good and the bad of network television's coverage of the war. As an actuality, the burning of the village had a tremendous impact on the viewer, and this was TV at its dramatic best. But on the other hand, were the pictures fair to the U.S. and to the Marines? Or was the message of the film somewhat out of balance? The pictures from Cam Ne had the impact of being the whole story of the war in Vietnam. But it was not the whole story, because the television camera accentuates only a very small

${ }^{61}$ Ibid.

62 Ibid., p. 46. 
part of the total action.

Time magazine summed up the matter in these words:

To try to put pictures of one village burning into proper context, to balance that one incident against all the other activity that makes up the war in Vietnam, would be all but impossible. On TV news, pictures make their own frontpage context; it takes a skillful script indeed to give them an added dimension, to remind the viewer that they are only part of the story. 63

Vietnam perspective. "It is almost as important to understand this war as it is to win it," summed up Friendly. ${ }^{64}$ For this reason he acheduled an unprecedented four part series on the Vietnam crisis in the late summer of 1965 at a time when the role of the U.S. in Vietnam rapidly was being expanded into the largest American military operation since Korea .

Friendiy believed there had been two basic flaws in earlier coverage of Vietnam: the problem was so vast and complex that no single broadcast could cover the subject adequately, and the form of the earlier broadcasts, be they debate, teach-in, or documentary, tended to develop more

63"Television: The Most Intimate Medium," Time, LXXXVIII (October, 14, 1966), p. 58.

${ }^{64}$ The staff of CBS News, vietnam Perspective: CBS News Special Report (N.Y.: Pocket Books, Inc.,1965), preface. 
heat than light. So the purpose of the planned new series was to clarify U.S. national policy toward Vietnam by covering the military and diplomatic aspects of our commitment, and also present an on-the-spot picture of the kind of war we are fighting.

To secure the necessary cooperation of the Administration, Friendly and members of his staff met with Presidential News Secretary Bill Moyers, who relayed the proposal to the President along with a request for participation by members of the cabinet.

The approval was forthcoming, and so the series began its analysis of the Vietnam situation by starting with the policy makers. The two men most directly responsible for U.S. actions in Vietnam next to President Johnson, Defense Secretary Robert McNamara and Secretary of State Dean Rusk, appeared on the opening broadcast on August 9 to discuss the critical decisions facing the Administration in a program called "The Decisions."

Each of the four programs in the series was one hour long, and the questions asked the Administration officials were designed to reflect all of the criticism of U.S. policy. In this way the officials were given an opportunity to pre- 
sent what amounted to a statement of national purpose.

General Maxwe11 Taylor, who had just returned from his post as ambassador to Saigon, appeared on the second broadcast a week later with General Earle Wheeler, Chairman of the Joint Chiefs of Staff. This program was devoted to a discussion of military operations and problems under the title of "How We Can Win."

On August 23, the third broadcast in the series was presented. It was called "Winning the Peace" and featured a return by Secretary of State Rusk, who was joined this time by U.N. Ambassador Arthur Goldberg and Presidential Assistant McGeorge Bundy. The purpose of that program was to discuss the Administration's diplomatic offensive toward a peaceful settlement of the Vietnam situation.

"A Day of War," part four of "Vietnam Perspective," examined Vietnam not from the point of those who argue about it, but from the point of view of those who must fight it every day. It was broadcast September 6 .

To get the color film for that one broadcast, CBS News used five correspondents and 15 cameramen. They were then deployed over Vietnam to report simultaneously what was happening on that one day of the war. Bernard Kalb reported 
from Ton Son Nhut Air Base, near Saigon. Murray Fromson covered the day's activity aboard the aircraft carrier Oriskany. Correspondent Peter Kalischer acconpanied a Marine company on a sweep through Vietcong territory. Morley Safer reported on the work of a Special Forces team in the Mekong Delta, and Charles Collingwood went on a flying tour of several battlefronts with General William Westmoreland, U.S. Commander in Vietnam.

The film was then sent back to New York for editing, and the small army of men marshalled for the shooting in Vietnam returned to their regular posts. Aside from whatever else it achieved, "A Day of War" was cited for excellence by the National Press Photographers Association and the University of Oklahoma School of Journalism 23rd Annual TV-Newsfilm Pictures of the Year Competition.

Running a total of four hours, "Vietnam Perspective" was a most ambitious undertaking for CBS News. But it was presented at a critical turning point in the war--when the U.S. was starting its massive troop build-up in vietnam in an effort to turn the tide of the fighting. At a time when broadcast journalism is often criticized for a lack of depth, this program provided the viewer with a detailed explanation 
of the U.S. commitment in Vietnam.

The colonel loses a leg. Undouttedly, some of the uneasiness in this country over the war in Vietnam can be directly attributed to television's coverage. For TV has brought into the American home vivid scenes of the horror and agony of the battlefield, and to many this has been a shattering experience. One of the most memorable such scenes was carried on NBC's "Huntley-Brinkley Report" on the evening of December 13, 1965.

A few days before, U.S. troops became engaged for the first time on a large scale against North Vietnamese regulars in what the American military called "Operation Harvest Moon." The role in that fighting for Marine Colonel Michael Yunck, a 25 year veteran in the Corps, was to direct air support from $s$ helicopter for troops moving in on an enemyheld village in the Ia Drang Valley.

But now Colonel Yunck lay on an operating table in a hot hospital tent, because he had decided not to call air strikes against that village when it appeared that the vietcong were using women and children as a shield. His humanity cost him his left leg, because he was hit by enemy machine- 
gun fire from the village when his helicopter swooped down for a closer look.

As a surgical team hovered around him, and an NBC camera recorded the whole scene in color, Colonel Yunck talked:

I've got a lot of pain in that left ankle. I think it's a good sign. It's that sharp pain that you get when you've got nerves, you know. It's that sharp nerve pain . . . burning, burning.

A doctor replied, "We' 11 do all we can to save that leg."

I know, I know there's not much left, because I was carrying that damn thing in my hands all the way back. I was afraid the whole thing was going to come off. I said, 'Hell, they can't be right around here.' So I didn't call bombs and napalm on those people. But that's where they were. I'm sure now that that's where they were. Goddamnit, I hate to put nape on these women and children. I just didn't do it. I just said, 'They can't be there.'

Well, we held the planes... We figured we'd cail them if we needed them . . . I swooped down 100 or 200 feet over this village, this hamlet area. I thought I saw some people in the hole, and I just hung arcund there ton long . . . and $I$ was too low . . .65

The circumstance of the filming was unusual in that it was shot with permission of the Marine Corps and also of ${ }^{65}$ Kroeger, (May, 1966), ㅇ․ it., p. 24. 
Colonel Yunck. The Colonel wanted it shown to students at the University of California at Berkeley who were at that time protesting against U.S. brutality and our involvement in Vietnam.

It was strong stuff, especially in color. But according to Robert Northshield, executive producer of "HuntleyBrinkley," there was no question of running it. "The only real decision was how much could we stand. What Yunck had to say was important." 66

Still, many viewers missed the point, and NBC had angry letters complaining of the Colonel's use of the word "Goddamnit." Northshield replied:

We edited carefully, left in 'Goddamnit.' It was said in a Christian way . . . Yet we get the Bible-belt mentality. They ignored the bigger fact--a fine man had his leg shot off. You keep getting cut up by the lack of sophistication of your asdience. There are 20 million people out there watching us, and they are not all thinking alike. 67

Incidentally, the Marine Corps was satisfied with the Colonel Yunck story, unlike Morley Safer's report on the

${ }^{66}$ Ibid.

67 Ibid. 
burning of Cam Ne, since for millions of Americans it showed a brave man at a tragic, yet momentous, point in his 11 fe.

The Fulbright hearings. In the winter and spring of 1966, all three networks carried live coverage of the Senate Foreign Relations Committee hearings which were being conducted by committee chairman J. William Fulbright. The hearings made big news as the committee questioned a number of government experts on the U.S. Involvement in Vietnam. Other sections of this chapter have given examples of the impact of sone of the networks' Vietnam coverage outside the industry. But in the case of the Fulbright hearings, one finds the best example of a controversy created within the industry because of TV's coverage of Vietnam. The dispute began in early February when John Schneider, newly appointed to the number three post in the CBS hierarchy, decided against live coverage of testimony by George Kennan, former U.S. Ambassador to Moscow. His reason was that he felt few persons were watching the prolonged hearings, and that a greater service was rendered by extracting the hard news and presenting it in compact evening newscasts which had far larger audiences. Schneider also pointed 
out that a majority of the country's opinion makers were at work during the time of the hearings and, therefore, would get a chance to see only the evening news programs. However, the week before CBS had canceled its regular programming to carry live the testimony of other witnesses before the Fulbright committee.

CBS News President Fred Friendly felt that televising the extended hearings would be beneficial in familiarizing viewers with the intricacies of the vietnam problem. Friendly could point out that since it has been established many times that television is the primary medium through which many millions of Americans obtain their knowledge of world events, not only does TV have a reportorial task but also a supplementary educational function. His over-all position was that the educational value of the full hearings could not be conveyed in spot news bulletins, and that extensive details were essential to understanding the complexity of the war.

Because CBS falled to carry the testimony of former ambassador Kennan, Friendly resigned, claiming that Schneider lacked adequate experience in national and international affairs to have a veto over the news department of CBS. He 
said that Schneider's decision was "a business, not a news judgment." 68

The shock created within television by the sudden resignation of Friendly far exceeded that of any other recent shake-up, but it tended to obscure the key question of the dispute which was how best to bring TV's skills to bear in covering the debate over U.S. foreign policy in Vietnam. According to Television magazine, another element in the rift may have been the coverage of the war itself by CBS News. It pointed out that Friendly was under pressure from the Pentagon because of the Safer report the previous August about Cam Ne. Therefore, it may have become a point of honor for Friendly to give full coverage to an antiAdministration viewpoint such as Kennan's, particularly since General Maxwe11 Taylor and Secretary of State Dean Rusk were able to air their views in full over CBS. ${ }^{69}$

But The Saturday Evening Post said of the matter:

For though Friendly was right in insisting that TV journalists be free to rely on their own news judgment, and though there is much to be said for

${ }^{68}$ The New York Times, February 16, 1966, p. 1. ${ }^{69}$ Television, XXIII (March, 1966), p. 8. 
telecasting news events live, as a public service, and though the Fulbright hearings were an important event, shedding some light on our murky commitment in Vietnam - granted all this, is it really good news judgment, and good journalism, to devote hours of broadcasting time to a verbatim presentation of a Congressional hearing? Or is it the exact opposite of journalism?

Outside of television, no journalist operates as a recording device. No war correspondent cables home every detail of the battle he covers, no trial reporter files a complete transcript of the testimony in court . .

However, Jack Gould, the influencial broadcasting critic of The New York Times, felt that TV's influence raised the level of the Senate Foreign Relations Committee hearings to the level of a constructive debate on vietnam. ${ }^{71}$ But he said that the uproar over the Friendly-Schneider dispute tended to obscure the fact that commercial TV had been inexcusably slow in digging out the controversy over the Vietnam war. Close-ups of the arama on the battlefield have their place, he said, but in his mind TV still had a major educational role to perform in acquainting the mass

\footnotetext{
70 The Saturday Evening Post, CcxxxIX (March 26, 1966), p. 120 .

${ }^{71}$ The New York Times, February 14,1966, p. 59.
} 
audience with the realities of a changing Asia. ${ }^{72}$

Gould also said that the whole thing tended to point out the nature of television to have friction between moneyproducing entertainment and cost-ridden journalism. ${ }^{73}$ He concluded:

As matters now stand, it is the entertainment side of TV that carries the most weight in daily operations. It is the news side that must jostle, plead, or beg for entry into the home screen. At times of national serenity, the set-up may be of scant consequence to the viewer. But at a time in which it is being decided whether the nation and the world are to know peace or war, the ground rules must be changed.

Television's challenge is to recognize that, as the nation's most influential force on public opinion, it is different from other businesses. In its responsibility there is a built-in limitation on profit... Mr. Friendly's resignation was in the nature of a reminder that, if $\mathrm{TV}$ fiddles while Vietnam burns, none of television's usual expedient arguments of the status quo will mean a thing. 74

But historian Arthur Schlesinger, Jr., said that the televised hearings represented an important success for the

72 Television, XXIII (July, 1966), p. 41.

${ }^{73}$ The New York Times, op. cit., p. 59.

${ }^{74}$ The New York rimes, February 20, 1966, Section II, p. 23 . 
networks :

I have no doubt that future historians wi11 conclude that these hearings opened a new phase in the Vietnam debate. Before the hearings, most people had suppressed any disquietude they may have felt over the deepening national involvement in Vietnam on the assumption that the President had more information and no doubt knew best. But the hearings had the clear effect, for better or worse, of legitimatizing dissent. If eminent generals, diplomats and senators were unhappy about our actions in Vietnam, then the ordinary citizen felt free to indulge in his own doubts . . Would these hearings have had the same effect had they not been on television? I think plainly not - and all the more credit therefore to the NBC network which carried them in full. 75

Eric Sevareid on vietnam. As a picture medium, one of the great advantages of television is its ability to bring the scene to the viewer, for this is what TV was designed to do. But much of the vietnam story concerns what goes on in the minds of wen and cannot, therefore, be expressed in visual terms. In addition, much of the information out of Vietnam is of a conflicting nature. Therefore, this provides a great opportunity for the commentator to use his talents in clarifying the situation somewhat by lending perspective

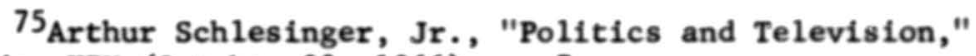
TV Guide, XIV (October 22, 1966), p. 7. 
and background to the Vietnam story. In-depth commentary is accepted on radio, but for a conmentator to sit down in front of a TV camera and read his carefully prepared script for a half hour or so is something we do not expect on television. Yet on June 21, 1966, CBS News used that approach in a 30 minute program called "Vietnam: Eric Sevareid's Personal Report." The program was sort of an essay combined with interpretation and commentary. Only a few visuals were used; the half hour was mostly Sevareid talking into the camera .

Among other things, he questioned the accuracy of American casualty figures and predicted that attempts to make democracy work in Vietnam could lead to years of instability as conflicting factions maneuver for power. Sevareid concluded his half hour by saying the real issue in Southeast Asia is social and economic liberation of the individual.

It was something that has rarely been seen on network television. But to broadcasting critic Jack Gould, it was the right approach, since he believes that when a country's chips are on the table, the public will sit still for 
illuminating commentary - even on television. ${ }^{76}$

Actually, the program said little about vietnam that had not already been covered in the nation's press. But Gould applauded the effort as "a step in the right direction of allowing TV correspondents more leeway in advancing their own opinions and frankly labeling them as such."77

Less than a month later, $A B C$ News presented a similar program on its "Scope" series. It was called "Howard $K$. Smith: One Man's Opinion." Although the researcher knows of no like network efforts since that time, still one cannot help but believe that more such programs will be presented in the future now that vietnam has provided an opportunity to show that there is a place on network television for programs devoted to commentary.*

A father interviews his son. On July 4, 1966, ABC tried a different approach on its weekly "Scope" series, and

${ }^{76}$ Gould, February 13), 1966, ㅇp. 소., p. 17.

${ }^{77}$ The New York Times, June 22, 1966, p. 95.

*Additional information on the networks' policy toward commentary and editorializing is contained in Appendix B on page 143. 
the resulting 30 minutes would be very hard to top for emotional content. That evening Howard $K$. Smith talked with his son, Specialist Fourth Class Jack Sinith, who suffered multiple wounds during the battle of the Ia Drang Valley in late 1965. At the time of the interview, he still had 50 pieces of shrapnel in his legs.

The program was called "A Father, A Son, and War" and was conducted much like a family discussion at home between father and son. The senior Smith was largely confined to conveying the worry, pride, and relief that would naturally be expected of a father in such circumstances. Most of the talking was done by the younger Smith, and he told of the fighting as he experienced it, the nightmare of the crying wounded and the horrors of hand-to-hand combat. For a while the enemy even mounted a machine-gun on what they thought was his lifeless body.

In such a program it is very difficulc for the viewer not to become emotionally involved, and this must be especial1y true for those parents with sons still in Vietnam. Some thought the half hour was too vivid. The New York Times commented that the program did underscore that "all war is 
he11. But to make the point through a family reunion that many fathers will never know could be construed as a lapse of sensitivity in wartime." 78

Summary. The examples in this chapter are representative of the type of Vietnam product which the three networks present. What kind of conclusions can thus be formed? First, the picture presented from Vietnam is generally uncompromising and hard hitting. The fact the networks produce such a variety of programs on Vietnam, particularly the talk programs like the Senate hearings and Eric Sevareid's half hour, is an indication that a determined effort is being made to present the whole picture on Vietnam.

Unfortunately, this picture is sometimes slightly out of balance because of the 1imitations of the medium, as indicated in the sequence from Cam Ne. However, this one report probably did more than any other to focus attention on the impact of television's Vietnam coverage.

The reader should also note the attempt made by a11 three networks to fulfill their educational roles by present-

\footnotetext{
${ }^{78}$ The New York Times, July 11, 1966, p. 59.
} 
ing live coverage of the Senate Foreign Relations Committee hearings. Since thousands of dollars of commercial advertising were lost when entertainment shows were dropped in favor of the hearings, this again 1llustrates the desire of the networks to give the viewer as complete a picture as possible on Vietnam. But the fireworks at CBS over live coverage of the hearings pointed out once again the commercial-entertainment side is in control of network TV and, therefore, has the last word.

Finally, particular attention should be given the long, one-man commentaries which have been a product of the war in Vietnam. It could be that this is the start of a trend to allow the most knowledgeable network correspondents more leeway in interpreting the complex news of our day.*

*A list of many of the special programs on the Vietnam war that the networks have presented is included in Appendix C on page 147. 


\section{CHAPTER v}

\section{TV'S COVERAGE OF VIETNAM: WHAT PEOPLE SAY ABOUT IT}

So far this study has been devoted mostly to the problems and difficulties faced by network television in covering the war in Vietnam. But with a few exceptiens, little has yet been said of the response this coverage has received. Therefore, the purpose of this chapter is to explore representative comments which have been made about TV's reporting of the conflict.

The researcher felt that the most knowledgeable remarks on TV's Vietnam war coverage have been made by those who deal with that coverage every day: the professional critics, spokesmen for the U.S. government and the military, and, of course, people in the industry itself. As a result, this chapter is divided into three sections, each given to corments from one of these groups.

What the critics say. In studying the columns of the professional critics, both broadcasting and otherwise, the researcher found one common theme through most of their 
comments: that TV's coverage tended to subordinate the cultural, political, and social implications of Vietnam for che stark drama of the battlefield. Another common criticism was that the TV correspondents have not been able to extract much sense from their string of battlefield vignettes.

As Brock Brower pointed out in Life magazine:

Difficult war aims and delicate policies are simply not rendered any clearer by the genuine bravery of a correspondent putting on tape his own entrapment by vietcong snipers and, belatedly, the networks seem to have realized

Dean Edward W. Barrett of the Graduate School of Journalism, Columbia University, agreed that trying to make sense out of the political morass in Vietnam has presented difficulties for the networks, resulting in a general tardiness in a discussion of the central and fundamental issues. He implied that some of this could be because almost none of the correspondents in Vietnam speaks the native language, and even some of the ablest of the younger correspondents have a relative shortage of political sophistication, especially when faced with the confusing currents and sub-

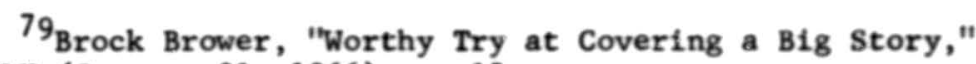
Life, LX (January 21, 1966), p. 15. 
currents of Vietnamese politics. 80

Network television also has been criticized for

failing to provide a balanced and factual picture of the war. This is especially the feeling of Hanson W. Baldwin, the military expert for The New York Times. He noted that the Vietnamese war is probably the most difficult and complex war to report ever covered by the American press, but he added:

Yet there are few editors who are willing or able to allocate the . . . time required for real in-depth reporting. Too often the day-today reporting is brief, episodic, and partial. For this, the editors . . . and television producers, not the correspondents in Saigon, deserve the blame. 81

Baldwin summed up the feelings of a number of other critics when he complained of distorted, biased, and sensational reporting by a few younger members of the TV corps. In addition, he said, some television reporters have delivered generalized editorial judgments for which they have neither the competence nor the knowledge to sustain, although

80 Notes taken from audio tape, "Television War Correspondent: The New Breed," op. cit.

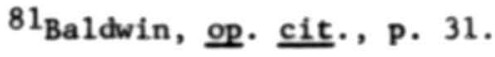


he noted the worst offenders have now departed. ${ }^{82}$

Military historian S.L.A. Marshall has been critical of TV's coverage of the war, pointing to television crews who "want blood on the moon every night." He also suggested that all too often searches are made only for what he called tangents and sidebars. These offbeat yarns, he said, "fall into several familiar patterns, none of which promises a beat any longer, though collectively, they are beaten to death. Any demonstration or riot is surefire copy." 83 Others also complain that television's coverage sometimes has a show biz look and can point to the fact that South Vietnamese government troops even have been known to hold up an operation until the TV crews arrived.

Another problem was pointed out by James Reston in one of his columns in The New York Times. He reminded his readers that the television cameras are only on one side of the lines, and so record mainly our casualties and the pathetic scenes of the South Vietnamese refugees overrun by

82 Ibid.

${ }^{83}$ Time, LXXXVIII (October 21, 1966), p. 86. 
our troops. ${ }^{84}$ But, the reader should realize that this problem is beyond the control of the networks, with the exception of what little footage they can secure from Oriental film agencies with contacts in North Vietnam. Another common complaint was voiced in The New Repub-

1ic:

On program after program, we are given the official line of advocates pro or con, couched in either the gobbledegook of government handouts or the jargon of protest. The lack of intelligent questioning only solidifies the rationales of the proponents of either view about the war . . . One expects television to excel on the visual level, but one hopes that a documentary can serve as comment as well.

There are no easy answers. Perhaps there are no answers at all, only decisions to be made. But for the networks to ask the questions is at least an attempt to thaw frozen attitudes. ${ }^{85}$

But network TV also has been praised for its efforts

in covering V'tetnam. Jack Gould wrote in The New York Times:

The initiative and bravery of the TV correspondents, and more particularly, the unsung cameramen who venture to the front lines, with all their bulky equipment will eventually stand

${ }^{84}$ The New York Times, February 18, 1966, p. 32.

${ }^{85}$ John Gregory Dunne, "The Networks on Vietnam," The New Republic, CLIV (January 8, 1966), pp. 36-37. 
as a remarkable chapter in electronic journalism. ${ }^{86}$

Dean Barrett told the New York NATAS forum on the television war correspondent that on the whole he was compelled to give network TV a rather high score for its coverage of Vietnam. He added that he thought the network journalists in Vietnam deserved "double A plus marks for enterprise, courage, perseverance, and fortitude." 87

But what would the critics suggest to the networks to improve their Vietnam product? The researcher wrote to a number of them and asked what single suggestion they would make, above all others, for the networks to better their coverage of the conflict.

Robert Lewis Shayon, broadcasting critic for the

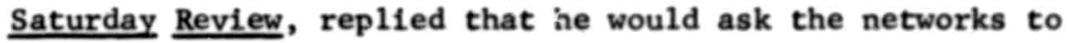
present other images of the war than those held by the U.S. government and by the majority of the news media in this country which, he said, generally reflect the government's

${ }^{86}$ Jack Gould, "How Is TV Covering Vietnam?", The New York Times, December 26, 1965, Part II and X, p. 15.

87 Notes taken from audio tape, "Television War Correspondent: The New Breed," op. cit. 
views of the conflict. ${ }^{88}$ Earlier he had pointed out:

There's no danger of cheating the Administration of its fair share of coverage; it cannot fail to get the lion's share anyway. It is the sharpest attacks of the critics that we must seek out and broadcast. I cannot remember which CBS correspondent said it . . . but it was well said, quoting President John F. Kennedy: 'The men who question power contribute as much as the men who use power. 89

The New York Times military expert, Hanson W. Baldwin, made a similar suggestion: "I would insist that any program dealing with the war should present a cross-section of opinion rather than the words of perhaps one faction or one man. $" 90$

However, Jack Gould of The New York Times pointed out that a balanced presentation of pros and cons is not enough. He said, because of the conflicting nature of much of the information on Vietnam, there is an urgent need for more interpretive commentary than is now being offered. According

${ }^{88}$ Personal letter from Robert Lewis Shayon, broadcasting critic for Saturday Review, dated October 10, 1966.

${ }^{89}$ Robert Lewis Shayon, "Giving the Doves a Break," Saturday Review, XLIX (March 10, 1966), p. 55.

90 Personal letter from Hanson W. Baldwin, Military Editor, The New York Times, dated October 12, 1966. 
to Gould, the viewer should have the benefit of dispassionate professional judgment to bring into focus the meaning of what he has seen or heard, and this means an assessment on celevision of the situation in vietnam by the journalists. 91

But the desire of most critics for TV to present a larger cross-section of opinion on Vietnam was typified by Shayon:

Certainly in an undeclared war, as in Vietnam, there is small justification for a parochial and limited establishment view. The more we permit a diversity of goals and strategies, the closer we may approximate a rational basis for policymaking. 92

Another suggestion for improving TV's coverage of the war came from Dean Barrett. He suggested that the networks get a more experienced corps of newsmen in Vietnam with the necessary language skills and peiftical sophistication required for accurate on-the-scene political reporting in that country. 93

For Jack Gould, the networks could improve their

91 Gould, (February 13, 1966), ㅇ․ it., p. 17.

${ }^{92}$ Shayon, (October 10, 1966), 오. c1t.

93 Notes taken from audio tape, "Television War Correspondent: The New Breed," op. cit. 
Vietnam coverage by fulfilling an educational need. He noted that in a sense, the dilemma of TV journalism is the same as that faced by the nation itself. In the Europea. yars of the past, he pointed out, we were fighting within a framework of Western culture. But in addition to the military challenge, he indicated that Vietnam also poses a formidable educational challenge. The average American's knowledge of that part of the world is almost nonexistent, Gould said, and so TV might improve its role by providing more information on Southeast Asia and the way of 11 fe there. 94

Although critics do not always make the same suggestions for improving TV's coverage of the war, surely most would agree with the view of Brock Brower in Life magazine. He noted that a CBS-Gallup poll seemed to show that the public was flying blind in this war:

If - and permit me to emphasize that if if television's . . reporting has in part been responsible for this public attitude, then the networks should be mindful that an audience for a mature news program is still 40 times as large as the troops now committed

${ }^{94}$ Gould, (December 26, 1966), op. cit., p. 15 . 
to Vietnam, and that these (grograms). . . can with honor be continued. 95

What U.S. government and military spokesmen say. Because Washington has a vested interest in Vietnam, it is within government, and especially within the Pentagon, that one finds the greatest awareness of television's impact on the public, and the value of that impact for a cause. And one of those who is very conscious of the impact of network TV's Vietnam coverage is Arthur Sylvester, Assistant Secretary of Defense for Public Affairs, one of the most sensitive jobs in the Defense Department. As noted in chapter three, some members of the press corps attribute a number of their difficulties in covering this war to Sylvester's office. Certainly, he would never win a popularity contest among the television correspondents who have reported from Vietnam.

But despite the contention that seems to exist between some of the TV newsmen and Sylvester, he has had some kind things to say about the networks' efforts in Vietnam:

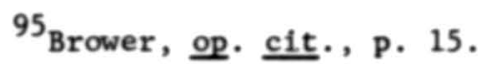


My observation is that, on the whole, television has done an excellent and courageous job in reporting the war. Some of the depth reports televisigp has done have been absolutely first rate.

But then he quickly added, "What is it, precisely, that the viewer at home actually sees? Is the picture, as he gets it, the same picture... seen by the soldier who actually experienced the reality?" 97

To Sylvester one of the biggest problems that TV presents for the Defense Department is that a television camera has a very limited field of view. He noted that since the cameraman cannot film everything when the action begins, he naturally films the most dramatic pictures. And according to Sylvester, the very fact that he is forced to select what to film makes him an editor as well as a cameraman. He also pointed out that while the cameraman might show vietnamese civilians huddled in fear, trying to avoid the shooting, the civic action that will take place in that same village after

${ }^{96}$ Arthur Sylvester, "But I've Seen It With My Own Eyes . . . !", unedited text of article submitted by Mr. Sylvester to Dateline, the journal of the Overseas Press Club, undated, p. 3 .

97 Ibid. 
the fighting has moved on will probably not be recorded, because the cameraman continues to go "where the action is." 98 Sylvester said that, as a result, the cameraman has shot a small action which is out of context with the whole, although he risked his neck to get it. If the cameraman is good, his film contains the most dramatic and moving pictures, but actually it generally tells only a partial story. By the very nature of the medium, Sylvester reminded, the cameraman cannot have seen everything. But when that film is shown on those $70,000,000 \mathrm{TV}$ screens, it appears to be the whole story. So for the viewer, the villagers huddled in fear will always remain that way, he said, and since the forthcoming civic action is not shown, there is no civic action. "There is only the sound of firing, the rush for cover, the man hit, the women and children weeping." 99

Sylvester concluded:

The television picture, because it is edited on the spot and contains such an immediate, dramatic impact, can give only a limited view. It is an inherent and built-in limitation of

${ }^{98}$ Ibid., p. 5.

${ }^{99}$ Ibid., pp. 6-7. 
the medium. The conventional pencil and notebook reporter can range as far as his mind and insights will take him - the reporter using film can range only as far as his camera can see...

This immediate response to a partial story causes no end of problems. The letters start coming in. Program viewers think they know what is going on. But what they have seen is usually only part of the picture. To give them the complete picture in words is a contradiction in itself. 100

Can network TV do anything about this problem?

Sylvester thinks it can if the broad picture of the war is brought down to the human equation. He concluded:

It would seem to me that in order to put his pictures into perspective, the correspondent will have to become a commentator on the action much in the same manner as the late Edward $R$. Murrow commented on the Blitz, from the burning rooftops of London. 101

There seems to be a general agreement in the Pentagon that the human side of the war needs more emphasis from the networks. General Harold Johnson, Army Chief of Staff, sided with Sylvester in a speech before the Oklahoma Press Association. He said that television could improve its

$$
\begin{aligned}
& 100 \text { Ibid., p. } 7 . \\
& { }^{101} \text { Ibid., p. } 8 .
\end{aligned}
$$


coverage of the conflict by pointing out "the many things our men over there are accomplishing as they work side by side with the Vietnamese people to improve living conditions and restore the local economic structure." He then reminded his audience that few pictures have been taken to show the military's civic action in battle-scarred villages. 102

General Johnson also told the Oklahoma Press Association:

I feel that an equally, or perhaps more important job can be done by journalists... here in the United States. The way news is played and interpreted has more impact on public opinion than the way it is written from the front. Editors and analysts would do well to look, not at single instances of gains or setbacks, but at cumulative effects of the skirmishes there. The nature of the enemy and the terrain forces us to press our attack in a series of sma11 engagements, and our defense is conducted against a hit-and-run foe. A news story on any given day may or may not be indicative of our progress toward success. 103

${ }^{102}$ General Harold Johnson, Chief of Staff, United States Army, an address before the Oklahoma Press Association Convention, Texoma Lodge, Lake Texoma, Oklahoma, June 11, 1966.

\section{${ }^{103}$ Ibid.}


However, more often than not the Army is pleased with TV's coverage of the war, especially the soldiers in the field who often feel forgotten. The sight of the networks' television crews is evidence to them that someone cares. As Ray Moloney of $\mathrm{ABC}$ noted:

The soldiers . . . are enormous ly pleased to have TV crews around. To them, it means somebody really cares about what they're doing. They' 11 share their last C-ration with you, and tie down your poncho tent properly so it doesn't blow away. I haye never felt more appreciated, nor more humble. 104

But even this can be a problem for the correspondents as they strive for objectivity. Regarding the effect such experiences can have on the TV reporter, Piers Anderton of $A B C$ pointed out:

He becomes so sympathetic and so admiring of the American military in the field that he, perhaps unconscious $1 y$, feels that he cannot be too critical, that he cannot report too harshly on the setbacks we encounter there. 105

It is here, at the field level, that the network people enjoy their best relations with the military. For their own safety, and the safety of the group, TV newsmen 
agree voluntarily to cooperate in the military way of doing things whenever they accompany allied troops on a mission against the enemy. This helps to promote a spirit of twoway cooperation. As a result, Lt. Col. Daniel Hill, Chief of the TV-Radio-Newsfilm Branch of the Directorate for Defense Information, said that the presence of the TV crews in Vietnam presents "little or no problem to the Army. Aside from routine logistics support in the field, TV crews are essentially self-sufficient and are accepted as a normal part of the military scene."106

The coverage of the war by the networks does, however, present difficulties for the Navy. According to Captain R.M. Koontz, the Navy's Director for Media Relations, the greatest problem of all is transportation, since much of the activity by the Navy is in waters off the shore of vietnam. But he indicated the Navy is making every effort to get the network crews out to ships so they can report on the job

${ }^{106}$ Personal letter from Air Force Lt. Col. Daniel Hi11, Chief, TV-Radio-News film Branch, Audio-Visual News Division, Directorate for Defense Information, dated November 7, 1966. 
which is being done in the South China Sea. 107

With the Navy so eager for more coverage, it is not surprising that the Department of the Navy has been satisfied over-all with TV's reporting of the naval story from Vietnam. Captain Koontz concluded:

The Navy in general has been pleased with the coverage we have received of our efforts in the war. We believe the parts of the story which have found their way into television homes around the country have done much to increase public awareness of the Navy role in the conflict, but we are anxious to get even more coverage of our work, and it is to that end that we are looking for ways to increase our manpower on the scene to meet the demands of the television correspondents. 108

And what does the Air Force think about the coverage of the war by network television? Major George Weiss of the Air Force Department of Information at the Pentagon said in a letter of reply that the networks have made a positive contribution in trying to explain to the TV audience the effort the Air Force puts into accurately hitting enemy

${ }^{107}$ Persona1 letter from Navy Captain R.M. Koontz, Director, Media Relations Division, Department of the Navy, dated October 18, 1966.

${ }^{108}$ Ibid. 
targets. He noted that television has corrected some erroneous impressions that the Air Force bombs indiscriminate1y. 109

Major Weiss, who had just returned as of this writing from a press relations assignment in Vietnam, also said that generally the networks have been helpful to the Air Force. He indicated that this was true, because the TV networks have perhaps been able to tell the Air War story to tiore people than the other media. "Personal experience has been that whenever the Air Force had a newsworthy effort which could be photographed effectively, the networks were eager to provide crews." 110

Although generally speaking the Pentagon is pleased with the networks' coverage of the war, still there are several additional points on which it has been critical of TV's efforts. After talking to a number of military and government officials, Neil Hickey of IV Guide listed the following

${ }^{109}$ Personal letter from Air Force Major George Weiss, Deputy Chief, Projects Development Branch, Public Information Division, Office of Information, dated October 5, 1966. ${ }^{110}$ Ibid. 
as the consensus of the Pentagon:

--Television is too engrossed with battle scenes, air strikes, and civil mayhem at the expense of the duller but more significant stories of Vietnamese politics, inflation, pacification, education, and construction of schools, etc. --That the camera's eye is too narrow to convey the full truth of a military action involving large units. As a result, the cameraman becomes an editor as he chooses to record the most violent and dramatic aspects of a military action.

--Viewers often receive a partial, out of context story, because TV crews too often move with the smaller units, like the squad or platoon, although what happens at that level has only minimal significance to the larger picture back at division headquarters.

--Many of the network correspondents are too young and inexperienced to convey fully the meaning of this complex war.

--That the networks have employed too many foreign nationals in their Vietnam bureaus*, and since many of these

*Admittedly, a number of the networks' cameramen and 
men are in such strong disagreement with U.S. policies, their opinions infect the quality of their reporting. 112

But in response to the researcher's question of the over-all attitude of the military toward the networks' coverage of the war, Lt. Col. Hill wrote in his letter of reply:

We believe that TV coverage of the war in Vietnam has been generally favorable to the military effort. For one thing, it dramatically acquaints the American public with the war . . . On balance, the exposure of Vietnam military activities through television has been beneficial. Generally, television news coverage . . . has reflected initiative and responsibility, although we would like to see greater emphasis on putting the story in perspective, as opposed to letting the sensational or isolated incident stand alone. Military blunders are a part of any war, and Vietnam is no exception. But such blunders are more than balanced by what is done right if the news repprter and his editor will seek a balanced view.

and soundmen are foreign nationals, including Vietnamese, French, Scandinavian, British, Korean, Australian, and Canadian. As noted in the second chapter, the networks must do this to hold down their expenses. But according to IV Guide, as of this writing all the men who do the talking, the network correspondents, are U.S. citizens, except Britisher Ray Moloney of ABC and Canadian Morley Safer of CBS. 111

${ }^{111}$ Ibid., p. 18.

112 Hickey, (October 15, 1966), 으. it., p. 14.

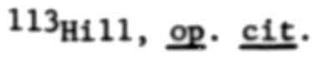


What the television newsmen say. One might think that the comments by TV newsmen about their network's coverage of the war would be only in defense of criticisms from other sources. But it is not the case, and this is a particularly healthy sign. For improvement can be made only when there is internal dissatisfaction with the product that is offered and some measure of critical self-evaluation. And for some of TV's newsmen to be dissatisfied with the coverage of the war suggests that improvement will be a constantly pursued thing as the networks become more experienced in covering this conflict.

Peter Jennings, the anchorman for $A B C$ 's evening news each weekday, is among those who believe TV is not doing an expert job of covering the war in Vietnam. Speaking before the New York NATAS forum on the television correspondent, Jennings agreed with the earlier criticisms that because of its limited field of view, the TV camera often records a story that is out of context. He also said it is true that since the networks are so competitive, they sometimes get a story out of Vietnam before it has solidified. 114

${ }^{114}$ Notes taken from audio tape, "Television War Correspondent: The New Breed," op. 소. 
Jennings admitted that because of the transportation problems in Vietnam and because of the very natuce of the war itself, the networks miss many stories they probably should have. But he added, "It is very difficult, perhaps impossible, for television to cover the whole war." He commented, however, that what many people did not understand, particularly people in government, is that TV is not the "be a11" medium in spite of the fact that there are millions of television sets in the U.S. Jennings said one of the reasons he does a 15 minute news program each weekday evening is in the hope viewers will then go and read their newspapers. But he concluded, "I regret that it is not very often true."115 NBC's Chet Huntley also has been critical of television's reporting of the war. He feels that too many reporters concentrate on the kind of action that insures an appearance on the air back home. 116

Howard $\mathrm{K}$. Smith of $\mathrm{ABC}$ agreed. He noted that during the Buddhist demonstrations in Vietnam, "television gave the

115

Ibid.

116 Time, (October 14, 1966), op. cit., p. 58. 
impression that the whole country was rioting, instead of 2,000 out of 17 million." He added that TV gives the idea that it's an American war. "You never see a Vietnamese action," he complained. 117

Then there is the fact that many of the network people in Vietnam are relatively young. Some of the older TV newsmen fear this is hurting the coverage of the conflict by television. One of them told Neil Hickey of IV Guide:

I'm disappointed in the over-all quality of the reporting. New York has, on occasion, sent misfits, people whose jobs were in jeopardy at home, and who were told to volunteer to come here - or else. They're untrained, or undertrained. They're an odd assortment of many nationalities - adventurers from all over the wor $1 \mathrm{~d} .118$

Another unidentified television newsman in Vietnam

said to Hickey:

I'm appalled that some correspondents are allowed to come here for as little as three months. They have no interest in Asian affairs. They're here to make a quick name for themselves and get out. Two years from now $I$, and a few others like me, will still be working in Asia, and that gives continuity to the reporting. Cov-

117 Ibid., p. 63.

118 Hickey, (October 8, 1966), ㅇ․ 스., p. 32. 
ering a battle is the simplest thing in the world. But to make sense out of what you've seen, both in the field and in Saigon - that's what these young hotshots can't do.119

But Charles Collingwood of CBS reminded Hickey:

Vietnam is the most physically demanding role that reporters have ever been asked to take. So it's a young man's war, and the coverage has all the failings and strengths of young men: it's more passionateg more colorful, and perhaps more erratic. 120

But even if some TV newsmen have not been satisfied with the over-all coverage of the conflict by their medium, the news executives at home have been pleased with the efforts of their staffs in covering the Vietnam story.

For William McAndrew, President of NBC News, the most satisfaction has come from "the devotion, courage, and professionalism of our correspondents in the field... and the concern of our news program editors here at home with detachment, substance, and good taste. 121

In response to the researcher's question of what has given him the most satisfaction in his network's coverage

${ }^{119}$ Ibid.

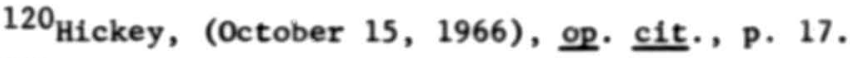
$121_{\text {McAndrew, 오. it. }}$. 
of the war, Richard Salant, President of CBS News, wrote:

That we have reported it exactly as we see it. We have reported the good as well as the bad. I derive great satisfaction from the fact that we have recognized from the beginning that the military action is only a part of the reporting of this war. And so we have focused as well on the vital non-military aspects - the political, the social, and the economic aspects. ${ }^{122}$

There was no reply from $A B C$ News.

Summary. The three groups with the most knowledgeable comments on the coverage of the war in Vietnam by network television are the professional critics, government and military spokesmen, and the TV newsmen themselves. On the basis of analytical comments from a number of them, several conclusions are suggested.

Generally, the critics praise the courage and initiative shown by the networks' men in Vietnam. But there is one common complaint: TV's coverage has tendad to subordinate the cultural, political, and social implications of the story to the drama of the battlefleld. Another repeated criticism by the press critics is that the networks were

122 Salant, 오. 다. 
generally tardy in discussing the central and fundamental issues involved with this conflict. There also have been some complaints of distorted and sensational reporting by television reporters.

When asked for ideas to improve IV's performance, the most frequent suggestion from the critics was that television present a greater variety of opinions on U.S. involvement in the war.

The recurring comment from government and military spokesmen about TV's coverage of Vietnam is that because of the camera's limited field of view, it sometimes gives a picture that is out of balance, although the viewer thinks that he is getting the whole story. There also seems to be general agreement in the Pentagon that the human side of the war needs more emphasis. In addition, the reader should note that the government and military have been critical of the fact that the networks employ a number of foreign nationals in their Vietnam bureaus, fearing these men are so against U.S. aims in the war that their reporting has been infected by personal opinions. But in response to this, it should not be overlooked that of all the TV correspondents who have 
served in Vietnam, only two of them are not U.S. citizens. However, despite these criticisms, the government and military seem generally pleased with TV's efforts in Vietnam and feel that, on-the-whole, the coverage has been beneficial to the war effort.

In surveying the television newsmen on the job network TV has been doing in Vietnam, one finds an awareness that some of the material presented has been slightly out of balance. There also seems to be a general agreement that network television can never cover the whole Vietnam story. Because of the limitations of television, it is pointed out that TV is not a "be all" medium, regardless of what othere might think. Another complaint among the newsmen themselves is that the quality of television's reporting in vietnam has suffered somewhat through men who were too young and/or inexperienced to effectively report from the scene. But the news executives back in the States are genera11y proud of the effort and the quality of the reporting by their men in Vietnam. 
CHAPTER VI

FINAL SUMMARY AND CONCLUSIONS

The purpose of this study has been to survey the coverage of the war in Vietnam by network television. More specifically it has been directed (1) to defining the problems that affect the networks' ability to cover the war; (2) to learning how the critics, the military, and the television Industry evaluate the war coverage; and (3) to reaching some conclusions on the performance of network television in its coverage of the conflict.

This concluding chapter is devoted to summarizing the most important findings of the survey and also to considering several final conclusions on necwork TV's efforts to present the story of Vietnam for the American viewer.

\section{SUMMARY}

Highlights of the study. The most difficult problem of all for television in covering vietnam is that of trying to make sense out of the tangled political situation there. Since the political story is largely one which is not visual, 
TV is handicapped in its attempts to present this side of the conflict for the American audience.

In covering the military aspects of the story, the networks are faced with serious transportation problems which are largely due to the guerrilla nature of much of the fighting. As a result, the biggest obstacle in presenting a complete picture of the military situation is one of logistics. Although getting good battle footage on film often is a matter of luck, still battle scenes remain at the hard core of TV's Vietnam reporting.

The network executives back in the States also are faced with the problem of getting enough good men to cover the war. But regardless of how many men are on the scene and despite their ability to overcome the difficulties in Vietnam, there is always that complicated problem of rushing exposed film back to the U.S. in time so that it won't lose its news value. The fact Vietnam is nearly 13,000 air miles and 13 hours away from New York causes many additional headaches .

Vietnam is also different from the recent wars in which the United States has been involved in that there is 
no formal censorship of the news. There are some restrictions imposed, ostensibly for reasons of military security, and described as of a voluntary nature. All three television networks as we11 as other news media have agreed to abide with these restrictions, and generally the Defense Department has been pleased with the cooperation it has received from the networks in this regard. However, there is a prevalent feeling that U.S. government officials have not always been completely honest with the press, and this has resulted in a "credibility gap," or a lack of belief by many reporters in the government's word. Because of this many TV newsmen place the blame for what they feel to be the inadequate reporting of the conflict on the government. But probably some of the difficulties in press relations are the result of misunderstandings between government and the press and particularly from the misquoting by the news media of a few government officials.

The area of censorship and press relations in vietnam is not to be taken lightly, because if a newsman does not follow the voluntary restrictions, he could lose his accreditation to cover the war. In addition, if strained relations 
lead to eliminating some of the help the military provides the TV networks, television would hardly be able to cover the military side of the story at all because of the transportation problems involved in getting crews and equipment into the field. However, the networks seemingly have little to fear in this regard, since each military branch is anxious to maintain TV's coverage of its contributions to the war effort.

The great variety of programs the networks present on Vietnam is a good indication of the determined effort they are making in attempting to present the whole picture of this conflict, and generally the picture that comes out of the millions of American TV sets is an uncompromising and hard hitting one. However, this visual treatment of the war is sometimes slightly out of balance because of the limitations of the medium.

The response this coverage has received from critics of the press is generally one of praise for the initiative and courage shown by the network reporters in Vietnam. But their one overriding criticism is that television's coverage of the conflict has tended to place the drama of the battle- 
field above the cultural, political, and social implications of the war. The most common suggestion from the critics to improve TV's performance is a desire for the networks to present a greater variety of opinions on U.S. involvement in Vietnam than they have in the past.

The most recurring comment from government and military spokesmen about the networks' coverage of vietnem is that the picture given is sometimes out of balance because of the limited field of view of a TV camera. There also seems to be general agreement in the Pentagon that the human side of the struggle needs more emphasis. Yet despite these criticisms, the government and military seem to feel that over-all the coverage of the war in Vietnam by the networks has been beneficial.

There seems to be a consensus among the network newsmen that television cannot cover the whole Vietnam story because of the limitations of the medium. Some also complain of inexperienced reporters who have been sent to cover the war in Vietnam for TV. But with the news executives back in the States, there is a general pride in the work done by television's men in Vietnam and in the quality of their reporting. 


\section{CONCLUSIONS}

Is the coverage adequate? The usual complaints against television news programs seem to be that TV news is superficial, it is too bland, and it rarely asks tough questions of leading government figures. Certainly none of the networks has claimed that TV's system of reporting is perfect. But in the half-hour weekly digests on the war, in the costly pre-emptions of entertainment programs, in the panel discussions, and simply in the willingness to spend such vast sums on Vietnam coverage, there is a clear indication that television is doing everything possible to illuminate the war's darker corners for the American viewer.

However, a more important question would still remain:

is the networks' coverage of the war adequate? The owners of many of those $70,000,000 \mathrm{TV}$ sets in the U.S. would probab1y think that it is. As Walter Cronkite of CBS noted, "We do such a good job, such a slick job, that we have deluded the public into thinking that they get all they need to know from us."123 Cronkite said this was a disturbing and fright-

${ }^{123}$ Television, XXII (November, 1965), p. 19. 
ening fact about the American people: we are a nation that exercises our precious franchise on the basis of incomplete knowledge acquired from headlines and news bulletins. 124 Referring to television's journalistic efforts, Cronkite said the medium has been given a responsibility "which in all honesty and candor we cannot discharge." According to Cronkite it is "impossible by the spoken word . . to communicate all the information that the individual citizen needs" to carry out his responsibilities. 125

So this is the problem that television is faced with in covering the story in Vietnam or any other news event. The time factors on each network program limit what can be said whether on a newscast or a panel discussion. A newspaper or a magazine can always add more pages if they are needed, but the space on TV is measured in minutes. Since each network program is designed to fill a specific length of time, no more minutes can be added. Therefore, many facts about what is going on in Vietnam must obviously be left out of the networks' coverage of the conflict.

\footnotetext{
${ }^{124}$ The staff of CBS News, ㅇp. 스., Introduction. ${ }^{125}$ Television, (November, 1965), 으. cit.
} 
This is particularly true on the evening newscasts in which the average story runs about a minute to a minute and a half. It is impossible to develop large-scale understandings with such snippets of time, and so some distortion is bound to result. This is simply one of the limitations of television, and one which is not made any more simple by a confusing and complex story like the one in Vietnam.

However, if a viewer could see all the Vietnam material shown on the three networks, he would be well informed on the situation there and its related aspects. But, of course, this is impossible, because the local station might not carry somp of the specials; sometimes a Vietnam program on one network will conflict with a similar show on another channel; and naturally the average viewer does not build his whole day around the TV programs on the home set. So the normal person does miss much of what is presented by the networks on the subject of Vietnam. And unlike reading a newspaper or a magazine at his convenience, he cannot pick up these programs at some other more opportune time once they have been missed. But for the viewer, TV is not essentially a news disseminating medium anyway as are newspapers 
and magazines. 126 He turns to television more often for entertainment than for news.

For these reasons network TV can never really do a completely adequate job of covering everything related to the Vietnam story. It can and is doing a very professional job, but as pointed out earlier in this study, television is not a "be a11" medium, and in the case of vietnam, adequate coverage, no matter whose definition were accepted, would still be wholly inadequate.

Also in an important sense, Vietnam is not the type of story television covers best. The biggest battles of the war go on in the minds of Vietnamese and U.S. officials who are searching for the answers. But these battles are not visual. They cannot be made into pictures, and pictures are the special business of TV. Yet, for many Americans, the short reports on the Huntley-Brinkley, Walter Cronkite, and Peter Jennings programs are the whole war, although almost every Saigon newsman agrees that these reports have emphasized the day-to-day activities over the more important background

126 Hickey, (October 22, 1966), ㅇ․ 도., p. 40 . 
stories. But where will they find the time? Confused by the politics in the cities, worn out by the fighting in the jungles, "we plod along," said Wendell Merick of ABC, "and delude... by not reporting enough on such things as the rural pacification and rebuilding programs in the villages." Then Merick concluded, "I don't think the American people are misinformed, but I think they are 111-informed."127

Neither can the networks provide the answers. Said NBC's Garrick Utley:

We can't do it, the Saigon government can't do it, the U.S. government can't do it. There's one big problem called Vietnam, and within Vietnam there are many small problems . . . We can illustrate these . . . but we cannot provide the answers, and this is why we are always going to have this confusion. 128

And, as pointed out by Neil Hickey of TV Guide:

Television's trickiest problem in Vietnam is to achieve balance between the seductive and the significant; to submerge the conviction that a scene of violence is important merely because a camera is recordigg it; to find substance behind the shadow.

${ }^{127}$ Time, (June 10, 1966), 요. it., p. 59.

${ }^{128}$ Notes taken from audio tape, "Television War Correspondent: The New Breed," op. 사.

${ }^{129}$ Hickey, (October 15, 1966), 오. 도.t., p. 16. 
Honesty and objectivity. When evaluating the honesty and objectivity of the networks' attempts to cover the story in Vietnam, one must realize that these words mean different things to different people. What is honest and objective reporting to one person might not be to another.

But in conclusion, it can be said that the TV networks are trying honestly to present what they consider to be a true picture of the war. Of course, these efforts are sometimes hamstrung by the complexities of the conflict, the limitations of the medium, and the normal fallibility of newsmen. It should be remembered, however, that the criticism some government officials have had of TV's coverage of Vietnam has resulted because the networks were determined to present what they felt was the real picture of the war as recorded by their camera crews and reported by newsmen on the scene.

Is the war coverage objective? A better question: is total objectivity ever possible? Probably not, and especially in such an argumentative atmosphere as surrounds vietnam. As already noted in this study, some of the TV newsmen are in support of U.S. aims in this conflict. But the fact that 
the television newsmen do have personal opinions on the story they are covering is an indication that total objectivity would be very difficult indeed. As Neil Hickey noted in TV Guide, total objectivity in Vietnam reporting is as elusive a quality as total candor among American and South Vietnamese officials on the war's prospects. "This standoff is built-in and not 1ikely to relax." 130

Yet since the men who run the television networks are Americans, too, they must feel the pressure of the news decisions they make. For how the war in Vietnam is reported and presented on TV will help to determine what this country will do there, and how to do it. In this conflict, more than in any other, the role of public opinion will largely decide if the war will be won. Because if the American public does not feel that the war is worth winning, this country faces ultimate defeat no matter how many military victories are gained.

So the researcher posed the question: do the networks ever subtly attempt to manipulate Anerican public opinion to support the U.S. war effort? The replies received were not

$$
{ }^{130} \text { Hickey, (October 22, 1966), 오. c1.t., p. } 40 .
$$


unexpected, but still they pointed out that objectivity and honesty take precedence over personal feelings.

Richard Salant, President of CBS News, wrote in reply:

You can stop wondering about any attempt to 'manipulate American public opinion to support our war effort,' subtly or otherwise. We don't and we won't. Our job is to report all the important facts and let the public make up its own mind. 131

William McAndrew, President of NBC News, added:

When the day arrives that any news organizations 'subtly attempt to manipulate American public opinion,' journalistic responsibility is gone and men of principle had best seek other occupations and students other life careers. 132

But the whole matter of honesty and objectivity was probably best summed up by Salant. While on a tour of vietnam in the fall of 1966 he said that some of the military and civilian officials felt that the TV reports were unfavorable to the war effort. Salant concluded:

We are probably achieving our goal of comprehensiveness and objectivity when we get charged

$$
\begin{aligned}
& { }^{131} \text { Salant, op. itt. } \\
& { }^{132} \text { McAndrew, ㅇ․ 다t. }
\end{aligned}
$$


at one and the same time of manipulating opinion to support the war and of manipulating opinion to subvert it. 133

Is anyone getting the message? Although the three television networks are spending hundreds of thousands of dollars on Vietnam coverage, some veteran reporters still feel that the American public is 1argely ignorant about what is going on over there. One of the most bitter complaints came from Malcolm Browne, who has been trying for five years to explain the Vietnam story to the American public, first as a Pulitzer Prize-winning writer for the Associated Press, and then as an $\mathrm{ABC}$ correspondent. As evidence, he cited a Stanford University poll which showed that seven out of ten Americans could not correctly identify the Vietcong as South Vietnamese Communists. 134

However, such misconceptions on the part of the public are really nothing new during wartime. In World War II and during the Korean conflict, public opinion polls showed that a similar state of confusion existed among the populace.

\section{${ }^{133}$ Salant, op. cit.}

${ }^{134}$ Newsweek, LXVIII (August 15, 1966), p. 54. 
But although the American public may not be as well informed as it should be, television newsmen in Vietnam can at least point to the fact that eight out of ten Americans polled by Stanford researchers knew that the Vietcong were the enemy. This caused Dean Brelis of NBC to remark, "I'd hate to think we don't get through at a11."135

What the future will bring. It has been pointed out earlier in this study that television has had nothing in its past to prepare it for an endeavor like the one it faces in covering Vietnam. One should not expect, therefore, that its reporting techniques would be fully developed at the outset. But the networks are learning, and their Vietnam product is improving. As noted by Arthur Sylvester:

Radio had the Czech crisis on which to warm up, Munich in which to begin to appreciate its broadcast possibilities, and the outbreak of World War II with which to perfect a format that served the public so admirably. I am convinced that television is going through the same sort of development. The long view, the whole story - these are the elements which have to be balanced with the on-the-scene picture. It can be done, and as television moves toward this

135

Ibid., p. 56. 
higher plateau of responsibility and achievement, it will contribute even greater service to the

There also will be a steady increase in the level of competency of the networks' day-to-day coverage of Vietnam now that they are firmly established there. As indicated by Peter Herford, Saigon bureau chief of CBS News, TV has already crossed a threshold in Vietnam; it is no longer a slave of the other reporting media. "The story you see on CBS," he said, "is a story we have unearthed.. . In terms of digging, we are fully competitive. Never before has this situation prevailed."137

But NBC's Garrick Utley reminded that things like this take time to develop in Vietnam. He said, in Vietnam the TV networks have been faced with a situation similar to that which confronts a newly arrived U.S. Army division. It takes weeks before the division is ready to fight after reaching Vietnam, he emphasized, because it must first learn the terrain, meet the people, and get itself established. Just

$$
\begin{aligned}
& 136 \text { Sylvester, op. cit., p. } 10 . \\
& 137_{\text {Herford, op. cit. }}
\end{aligned}
$$


as the military is then able to raise the level of its performance, Utley said, so will television. But all this does zake time, he concluded, "because you don't walk into Vietnam and starc giving definitive analysis." 138

The quality of the networks' Vietnam coverage had better improve, because by 1967 the responsibilities and problems for TV will multiply when a new cormunications satellite over the Pacific may make available live coverage of the war. Then television's first war will also become the first war brought into the American home even as it is being fought.

In fact, such live coverage is possible today. For example, Secretary of the Navy Paul Nitze told the 1966 convention of the Radio and Television News Directors Association in Chicago:

Today it is technically feasible to provide live television coverage of a strike against the Communists in Vietnam from a Seventh Fleet carrier in the South China Sea. In the same scenario, the American public can be eye witnesses to the recovery of the returning aircraft and see and hear the Navy pilots debrief

${ }^{138}$ Notes taken from audio tape, "Television War Correspondent: The New Breed," op. cit. 
their mission. It is also technically feasible that some missions could be covered live. 139

NBC President Julian Goodman told the convention that uven live coverage from the jungle battlefields will be a technical possibility in 1967.140 And according to ABC News President Elmer Lower, al1 that remains to make such live battlefield coverage a reality after the launching of that fixed satelite is a ground relay station.

Even though live coverage of the war in Vietnam is an exciting possibility, it will also tend to increase the burdens on network television. As CBS News President Richard Salant noted:

. . It is what one does with new tools... such as satellites... . and with television as it already is in terms of content and substance that matters. If we fail to convey the real meaning of the news, all of television's technological advances will not mean anything. For we will have galled at the 4 yery heart of what journalism is all about.

${ }^{139}$ Secretary of the Navy Paul Nitze, an address before the annual convention of the Radio and Television News Directors Association, Chicago, Illinois, September 29, 1966.

140

Broadcasting, LXXI (October 3, 1966), p. 54.

${ }^{141}$ Television Age, XIV (September 26, 1966), p. 67. 
Certainly live TV coverage of the conflict will pose new difficulties for the networks and will create new criticisms of their efforts to present an honest and accurate picture of the war. In referring to this problem ABC President Leonard Goldenson only mentioned his network, but he also was summing up the attitudes of the other networks when he said:

ABC will not be swayed by criticisms of our methods by the other news media. Nor will we be frightened by controversy or subjected to pressure from any source - be it government, special interest, or anything else. And we have no intention of using vietnam as a television rating game. We, and we alone, have responsibilit $\mathrm{y}_{4} \mathrm{q}^{\mathrm{f}}$ determining what is presented...

Related areas for study. As pointed out at the beginning of the study, the researcher hoped that this work might provide the foundation for other, more specific studies of television's coverage of the war and its effects on the American audience. Several such studies came to mind during the course of this research effort.

One big area for future study is that of audience

${ }^{142}$ Kroeger, (May, 1966), op. c1t., p. 44. 
reaction to TV's Vietnam coverage. It is generally accepted that much of the uneasiness in this country over the war in Victnam is a result of television. But more specifically how does the average viewer respond to such coverage? This is a vital question, because these people as a group form an important segment of public opinion, and their reaction to what is shown will, in the final analysis, largely determine what the United States does in Vietnam. If television is making this the most well-covered war in our history, why is there still so much dissent and confusion across the country about this conflict? Is television responsible for it?

Certainly the viewer is influenced in his thinking about the war not only by what he sees regarding battles and political turmoil in Vietnam, but he is also influenced by the reporting of draft-card burnings, sit-ins, and other types of demonstrations. Could it be that TV has given this side of the Vietnam story too much attention? Is television actually making the war unpopular, because it spends so much time and money to cover anti-war stories? These are questions which deserve to be answered. 
This study only focused on the coverage of the war by network television, but there are individual TV stations and chains like Westinghouse and Storz which have also attempted to cover the conflict for their particular audiences. However, most stations depend entirely in their locally-produced newscasts on pictures and copy from the wire services to tell the Vietnam story. This aspect of TV's Vietnam coverage should not be overlooked, because all of the coverage via television contributes to the public's awareness of the war. It may be difficult or impossible for the average viewer to single out how much he is affected about vietnam due to network TV, and to separate that from how he is influenced by local station reporting of the story. So a study of how local TV stations cover the conflict is another area for consideration.

The presidents of the news departments of two of the TV networks were quoted in the preceding pages as saying that the reporting of vietnam by their staffs is not aimed at manipulating American public opinion. But it is very possible that unintentionally public opinion is being manipulated anyway. A study of this problem would be most valuable. 
In the past there has been much debate over televising courtroom proceedings and legislative functions. The coverage of Vietnam by the networks also entered this area when the hearings of the Senate Foreign Relations Committee were presented live. Certainly this again showed that television can bring the citizen close to his government at work and without disrupting the legislative process. Thus a new opportunity is provided the researcher for studying the question of live television in legislative chambers.

This study concluded that network television can never cover every aspect of the Vietnam story for the viewer because of the limitations of the medium. This means that the 60 per cent of the population in this country that gets most of its Vietnam news from TV is 111 informed, especially since for most Americans the short reports on the networks' evening newscasts are the whole war. Does this mean that the networks are considering new ways in which to present their Vietnam product? Will the format of the evening newscasts be changed? Can the networks ever overcome such a problem, or is this just a limitation of the medium that must be accepted? 
In some cases the other news media face the same problems as television in covering the war. But they also are confronted with special difficulties of their own in Vietnam. What are these problems? And how do the press restrictions in vietnam effect the other media? This is another big area that needs to be explored.

A final thought. Visual war reporting has come a long way since the days of the box camera. But the picture reports of warfare will still anger and result in controversy, particularly those by network TV from Vietnam. Since this is not the kind of war that summons up a national determination to win at any cost, it is a very difficult war for television to cover with newly developed tools and techniques without incurring distaste and dissent within its audience. As pointed out by Dr. Frank Stanton, President of CBS :

There is an ancient proverb about the low regard in which the bearer of ill-tidings is held. 'None love the messenger who brings bad news,' wrote Sophocles. Unhappily, much of the news in any war is bad news, and this one is far from an exception. 143

${ }^{143}$ Stanton, op. cit. 
If network television is to continue to observe its journalistic obligations in covering the Vietnam story, it must expect to suffer constant and widespread rebukes from those who prefer to take their reality in milder doses than TV dishes out.

But the price for such vietnam coverage can be justified, because television's best product is not entertainment, but rather the recording and interpretation of actual events. Robert Kintner, past President of NBC, summed up the whole matter when he said:

On the day when those of us who have given our lives to the medium are called on to account for our time, the heaviest weight on our side of the balance will be this expansfon of reality for tens of millions of people.

${ }^{144}$ Rotert E. Kintner, "Televising the Real Wor1d," Harper's Magazine, CCXXX (June, 1965), p. 95. 
APPENDIX A 


\section{THE IMPOSSIBLE TAKES 20 HOURS}

As an example of the involved procese of getting news film from Vietnam to the States and on a network newscast, Clyde Bennett gives the following as a "typical" sequence. Bennett, chief of transport for $A B C$ News, is the man responsible for supervising the transportation of news film as rapidly as possible from the scene to a point where it can be broadcast. This was the sequence he reconstructed for the July, 1965, issue of Teleyision magazine:

"A bomb blast in Saigon or a military action close to the city is filmed by an $A B C$ News crew at $11 \mathrm{a} . \mathrm{m}$. Saigon time (10 p.m. NYT). The correspondent on the scene rushes the film to Saigon Airport by helicopter and cables ABC News in New York and Tokyo that the film is being shipped out of Saigon on the first available flight to Tokyo.

"The film is put on an Air France flight leaving Saigon at 1:15 p.m. Vietnam time (12:15 a.m. NYT). It arrives in Tokyo---3,000 miles away--at 8:50 p.m. Japan time (7:50 a.m. NYT), where it is met by an ABC News Tokyo staffer. Following a specially prepared airlines schedule that Bennett 
has previously provided a11 ABC overseas bureaus, the film is placed on a Northwest Orient Airlines flight in Tokyo at 9:45 p.m. Japan time (8:45 a.m. NYT) and ticketed for ABC News in New York.

"By this time Bennett, in New York, has phoned the $A B C-T V$ affiliate in Seattle, KOMO-TV, advising it to intercept the film package when the plane makes its scheduled stop-over at Seattle International Airport at 1:15 p.m. PCT (4:15 NYT). U.S. Customs officials at the airport also are alerted of the urgent film shipment by Bennett and asked to clear the film as quickly as possible.

"A motorcycle courier, waiting at the air terminal in Seattle as the plane touches down after its 7,250-mile flight from Tokyo, gathers up the film and rushes it to KOMO-TV, five miles away. There, the film is processed and screened by 2 p.m. PCT (5 p.m. NYT). A KOMO-TV news editor then phones Walter Pfister, the producer of ABC-TV's 15 minute 'Peter Jennings and the News' program--taped at 6 p.m. NYT for national showings in local time between 6-7:30--and discusses the film content and editing.

"The film is then edited and transmitted from Seattle 
to New York via coaxial cable for use on the Jennings newscast. Time elapsed: 20 hours. Mileage: $10,250 \mathrm{miles}$ by air, five miles by motorcycle, 3,325 miles by coaxial cable."145

${ }^{145}$ Kroeger, (July, 1965), 오. c1t., p. 75. 
APPENDIX B 


\section{MORE THOUGHTS ON COMEENTARY AND}

EDITORIALIZING

It appears that the time is coming when network television correspondents will have to be given the right to speak with more of a mind if sense is to be made of the complex news developments of our day. Certainly vietnam is an example of one story that is in definite need of expert commentary. What is the policy at the networks on comment and analysis on such stories? A few added thoughts on the subject from network executives:

William Sheehan, Vice President \& Director of ABC

Television News, said:

It is the policy of $A B C$ News to encourage qualified correspondents to provide background commentaries and analysis on Vietnam stories . . . I must confess, however, we have not come up with a final solution. No one has, and I guess that is what is so frustrating. 146

Reuven Frank, Vice President of News at NBC, explained how his network decides who has the right to provide commentary:

146 Personal letter from William Sheehan, Vice President \& Director of ABC Television News, dated October 5, 1966. 
The privilege is restricted, so far as we are concerned. It is given to some men more than others, and to some men not at all. It is given to some men in some situations, and the same men are not allowed it in other situations. 147

As for editorializing on Vietnam, or any other subject, this is against the policies of all three networks. They are required by regulation to fairly present both sides of any controversy. But since the stations that are members of a network are the licensees, the network must honor the views and responsibilities of these stations as well. Therefore, none of the networks editorializes.

As pointed out by Richard Salant, President of CBS

News :

It has been, and is, our conviction at CBS News that we have no monopoly on wisdom and no right to impose our personal conclusions on the American people. As Ed Murrow so often said, our job is not to make up our viewers' minds for them, but, rather to present viewers with all the relevant facts, analyses, and significant viewpoints so that they can make up their own minds, on a fully informed basis.

And so, in the future as in the past, CBS News does not propose to abandon its policy of balance, nor its policy against editorializing. We will

${ }^{147}$ Personal letter from Reuven Frank, Vice President of NBC News, dated October 31, 1966. 
analyze and interpret; we will not editorialize. 148

Reuven Frank of NBC summed up the whole matter of editorializing when he told the National Broadcast Editorial Conference at Columbia University that for the networks to editorialize "would be an imposition on several hundred stations which might or might not subscribe to the editorial opinion expressed."149

${ }^{148}$ Television Age, op. cit., p. 66.

${ }^{149}$ The New York Times, July 30,1966, p. 59. 
APPENDIX C 
Among the special programs on Vietnam that each of the television networks has presented are those on the following pages.

ABC News offered the following specials during 1966: March 10, 1966 - "Operation Sea War: Vietnam"

June 12, 1966 - "I Am A Soldier"

October 24, 1966 - "To Save A Soldier"

In addition, $A B C$ has its weekly half-hour show called "ABC Scope: The War In Vietnam."

The NBC News TV specials on Vietnam have been:

December 1, 1964 - "Vietnam: It's A Mad War"

Apri1 1, 1965 - "Vietnam: The Home Front"

December 20, 1965 - "Vietnam: December 1965"

September 11, 1966 - "Vietnam: War of The Ballot"

December 12, 1966 - "Our Asian War"

NBC also has its "Vietnam Weekly Review" and "Vietnam Report" each weekday on the "Today" show.

The list of CBS News TV specials is much longer, and one reason for this is the fact that CBS does not believe weekend wrap-up shows on Vietnam are effective, because it believes too many people are away from home then and, there- 
fore, don't see them. The following list was submitted to the researcher by CBS News as the TV specials it has presented on the war in Vietnam during the last two years:

January 11, 1965 - CBS News Special Report: "vietnam: How We Got in--Can We Get Out?" (1 hour)

February 7, 1965 - CBS News Special Report: "Vietnam: Air Strike North" (1/2 hr.)

March 8, 1965

- CBS News Special Report: "Vietnam: The Hawks and the Doves" (1 hour)

May 3, 1965

- "Town Meeting of the Wor1d" (1 hour)

May 15, 1965

- CBS News Special Report: "Washington Teach-in" ( 1 hour)

June 21, 1965

- CBS News Special Report: "Vietnam Dialogue: Mr. Bundy and the Professors" (1 hour)

August 9, 1965

- Vietnam Perspective (Part One): "The Decisions" (1 hour)

August 16, 1965 - Vietnam Perspective (Part Two): "How We Can Win" (1 hour)

August 23, 1966 - Vietnam Perspective (Part Three): "Winning the Peace" (1 hour)

September 6, 1965 - Vietnam Perspective (Part Four): "A Day of War" (1 hour)

October 26, 1965 - "Town Meeting of the Wor1d" (1 hour) 
November 30, 1965 - CBS News Special Report: "The Battle for the Ia Drang Valley" (1/2 hour)

December 14, 1965 - CBS News Special Report: "Where We Stand in Vietnam" (1 hour)

December 21, 1965 - "Town Meeting of the Wor 1d" (1 hour)

December 28, 1965 - CBS News Special Report: "Christmas in Vietnam" ( $1 / 2$ hour)

January 30, 1966 - Vietnam Perspective: "The Congress and the War" (1-1/2 hours)

February 1, 1966 - CBS News Special Report: "Fulbright: Advise and Dissent" $(1 / 2$ hour $)$

February 6, 1966 - Vietnam Perspective: "The U.N. and the War" (1 hour)

February 8, 1966 - CBS News Special Report: "The Councils of War" (1 hour)

February 13, 1966 - Vietnam Perspective: "Congress After Honolulu" (1 hour)

February 18, 1966 - Vietnam Perspective: "The Senate Hearings and the War" (1 hour)

March 13, 1966

- Vietnam Perspective: "China and the War" (1-1/2 hours)

Apri1 12, 1966

- CBS Reports: "vietnam: The Other War" (1 hour)

April 18, 1966

- Vietnam Perspective: "The Rusk Testimony" (1/2 hour)

Apri1 20, 1966

- Vietnam Perspective: "The McNamara Testimony" (1/2 hour) 
May 9, 1966

May 11, 1966

May 20, 1966

May 27, 1966

May 31, 1966

June 21, 1966

July 1, 1966
- Vietnam Perspective: "The Rusk Testimony" (1/2 hour)

- Vietnam Perspective: "The McNamara Testimony" (1/2 hour)

- Campaign '66: "Vietnam and the Elections" (1 hour)

- CBS News Special Report: "The U.S. and China" (1 hour)

- Vietnam Perspective: "The Anthony Eden Proposals" (1/2 hour)

- CBS News Special Report: "Vietnam: Eric Sevareid's Personal Report" (1/2 hour)

- CBS News Special Report: "Vietnam Perspective: The Decision to Bomb" (1 hour)

September 11, 1966 - Asia Perspective: "Election Day in Vietnam" ( $1 / 2$ hour) 
APPENDIX D 


\section{AWARDS FOR VIETNAM COVERAGE}

The three television networks have won many awards Eor their coverage of the war in Vietnam. Among those awards are these:

As anchorman for $A B C$ 's weekly half-hour series on the Vietnam war, "ABC Scope: The War In Vietnam," howard $\mathbf{K}$. Smith was cited by the Overseas Press Club of America for his penetrating commentaries on news from abroad during 1965 .

The awards won by CBS News for its Vietnam coverage include:

George Polk Memorial Awards of Long Is land University Awarded to CBS News Correspondent Morley Safer

National Press Photographers Association and the University of Oklahoma School of Journalism 23rd Annual TV-News film Pictures of the Year Competition Awarded to CBS News for Vietnam Perspective: "A Day of War"

Overseas Press Club

Two of the club's major awards given to CBS News Correspondent Morley Safer

George Foster Peabody Awards Awarded to CBS News Correspondent Morley Safer

Sigma Delta Chi Awarded to CBS News Correspondent Morley Safer

Paul White Memorial Award Awarded to CBS News Correspondent Morley Safer 
At $\mathrm{NBC}$ the awards include:

"Vietnam: It's A Mad War"

March 10, 1965 - 1964 - National Press Photographers Assn. First Place News Documentary

March 31, 1965 - 1964 - George Polk Memorial Award of Long Is land University

March 23, 1966 - 1965 - Writers Guild of America Award

Vietnam Coverage (In Genera1)

April 9, 1966 - 1965 - Saturday Review Award to NBC and CBS "For use of prime time, talent and resources to inform the American People on the critical issues in the Vietnam crisis; for sustained coverage of the war and the events surrounding it; for major special broadcasts and documentaries on the actual conflict and on the great national debate it has inspired."

Ron Nessen

October 10, 1966 - Awarded honorary Combat Infantryman's Badge in ceremony at Walter Reed Hospital, Washington, "in recoguition of his outstanding performance of duty as a combat infantryman serving in the Republic of South Vietnam against an active hostile ground force." 
BIBLIOGRAPHY 


\section{B IBLIOGRAPHY}

\section{A. BOOKS}

The staff of CBS News. Vietnam Perspective: CBS News Special Report. New York: Pocket Books, Inc., 1965.

\section{B. LETTERS}

Baldwin, Hanson W., Military Editor of The New York Times, October 12, 1966.

Frank, Reuven, Vice President of NBC News. October 31, 1966.

Herford, Peter, Salgon Bureau Chief of CBS News. October 15, 1966

Lt. Co1. Hill, Daniel M., Chief, TV-Radio-Newsfilm Branch, Audio-Visual News Division. Directorate for Defense Informat? on. November 7, 1966.

Captain Koontz, R. M., Director, Media Relations Division, Department of the Navy. Ostober 18, 1966.

McAndrew, William R., President of NBC News. October 5, 1966.

McClelland, L. A., Manager of Bureau Services, NBC News. October 7, 1966.

Mitgang, Herbert, Executive Editor of CBS News. October 7, 1966.

Salant, Richard, President of CBS News. October 12, 1966.

Sammon, Robert M., Director of News Operations, ABC Television. October 13, 1966. 
Sanders, Marlene, ABC Correspondent. October 12, 1966.

Shayon, Robert Lewis, Broadcasting Critic of Saturday Review magazine. October 10, 1966.

Sheehan, William, Vice President \& Director of ABC Television News. October 5, 1966.

Steinman, Ron, Saigon Bureau Chief of NBC News. October 12, 1966.

Major Weiss, George L., Deputy Chief, Projects Development Branch, Public Information Division, Office of Information, United States Air Force. October 5, 1966.

\section{PERIODICALS}

Baldwin, Hanson w. "The Information War in Saigon," The Reporter, XXXIV (February 24, 1966), pp. 29-31.

Broadcasting, LXX (February 7, 1966), p. 90.

Broadcasting. LXX (February 28, 1966), p. 90.

Broadcasting, LXX (Apri1 18, 1966), p. 56.

Broadcasting, LXXI (July 4, 1966), p. 41.

Broadcasting, LXXI (October 3, 1966), p. 54 .

Brower, Brock. "Worthy Try at Covering a Big Story," Life, LX (January 21, 1966), p. 15.

"Camera in Combat," Television Age, XIII (March 14, 1966), pp. 32-33, 70.

"Chopper Warfare," Newsweek, LXIV (September 14, 1966), p. 84 . 
"Covering Vietnam: Crud, Fret, and Jeers," Time, LXxxvII (June 10, 1966), pp. 54-59.

Dunne, John Gregory. "The Networks on Vietnam," The New Repub1ic, CLIV (January 8, 1966), pp. 36-37.

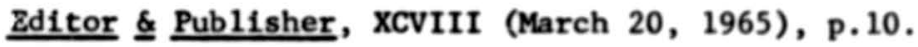

"Frank Ta1k," Newsweek, LXVII (January 3, 1966), p. 52.

Grafton, Samuel. "Television's Front Page," TV Guide, XIII (October 2, 1965), pp. 6-9.

Greenwald, Jean. "TV Newsmen Caught in 'Asian Hurricane'," Editor \& Publisher, XCVIII (July 24, 1965), pp. 36-38.

Hickey, Neil. "The Vietnam War: Is Television Giving Us the Picture?", IV Guide, XIV (October 1, 1966), pp.6-13.

Hickey, Neil. "Vietnam: Is Television Giving Us the Picture?", TV Guide, XIV (October 8, 1966), pp. 26-32.

Hickey, Neil. "Vietnan: Is Television Giving Us the Picture?", TV Guide, XIV (October 15, 1966), pp. 13-18.

Hickey, Neil. "Vietnam: Is Television Giving Us the Picture?", TV Guide, XIV (October 22, 1966), pp. 36-40.

Kintner, Robert E. "Televising the Real World," Harper's Magazine, Ccxxx (June, 1965), pp. 94-98.

Kroeger, Albert R. "Television's Men at War," Television, XXII (July, 1965), pp. 36-39; 71-75.

Kroeger, Albert R. "Vietnam: Television's Cruelest Test," Television, XXIII (May, 1966), pp. 24-27; 38-46.

"The Saigon Follies?", Newsweek, LXVIII (August 15, 1965), pp. 54-56.

Schlesinger, Arthur, Jr. "Politics and Television," IV Guide, XIV (October 22, 1966), pp. 6-10. 
Shayon, Robert Lewis. "Giving the Doves a Break," Saturday Review, XI.IX (March 5, 1966), p. 55.

Shepard, Richard. "They Only Point a Camera," IV Guide, XIII (November 27, 1965), pp. 16-17.

Sponsor, XX (May 2, 1966), pp. 22-23.

Television Age, XIV (September 26, 1966), pp. 34-36; 66-67.

"Television and Vietnam," The Saturday Evening Post, CcxxxIX (March 26, 1966), p. 120 .

Television, XXII (November, 1965), p. 19.

Television, XXIII (March, 1966), pp. 7-8.

Television, XXIII (July, 1966), p. 41.

"Television: The Most Intimate Medium," Time, LXxxviII (October 14, 1966), pp. 56-64.

Time, LXXXVIII (October 21, 1966), p. 86.

"TV's First War," Newsweek, LXVI (August 30, 1965), p. 32.

Tyler, Barbara Sue. "A Woman's View of the Vietnam War," Women's World, II (November, 1966), pp. 62-69.

\section{NEWSPAPERS}

Gould, Jack. "How Is TV Covering Vietnam?", The New York Times, December 26, 1965, Part II and X, p. 15 .

Gould, Jack. "Crisis in Need of Commentary," The New York Times, February 13, 1966, Part II, p. 17.

The New York Times, January 29, 1966.

The New York Times, February 11, 1966. 
The New York Times, February 14, 1966.

The New York Times, February 16, 1966.

The New York Times, February 17, 1966.

The New York Times, February 18, 1966.

The New York Times, February 20, 1966.

The New York Times, March 24, 1966.

The New Yoxk Times, June 22, 1966.

The New York Times, July 9, 1966.

The New York Times, July 11, 1966.

The New York Times, July 30, 1966.

Tolchin, Martin. "Vietnam: The Camera Goes Into Battle," The New York Times, April 17, 1966, Part II, p. 17.

\section{E. SPEECHES}

Cronkite, Walter, Managing Editor of "CBS Evening News". An address before the 1966 winter meeting of the Inland Daily Press Association.

General Johnson, Harold K., Chief of Staff, Inited States Army. An address before the Oklahoma Press Association Convention, Texoma Lodge, Lake Texoma, Oklahoma, June 11, 1966.

Nitze, Paul н., Secretary of the Navy. An address before the Annual Convention of the Radio and Television News Directors Association, Chicago, I1linois, September 29, 1966. 
Stanton, Frank, President of CBS. "The Face of War," an address at the Waldorf-Astoria Hotel, New York City, January $28,1966$.

\section{F. UNPUBLISHED MATERIALS}

Sylvester, Arthur, Assistant Secretary of Defense for Public Affairs. "But I've Seen It With My Own Eyes," unedited text of article submitted by Mr. Sylvester to Dateline, the journal of the Overseas Press Club, undated.

"Television War Correspondent: The New Breed," a forum of the New York Chapter of the National Academy of Television Arts and Sciences, New York Hilton Hote1, March 23, 1966. Notes taken from audio tapes of the forum. 

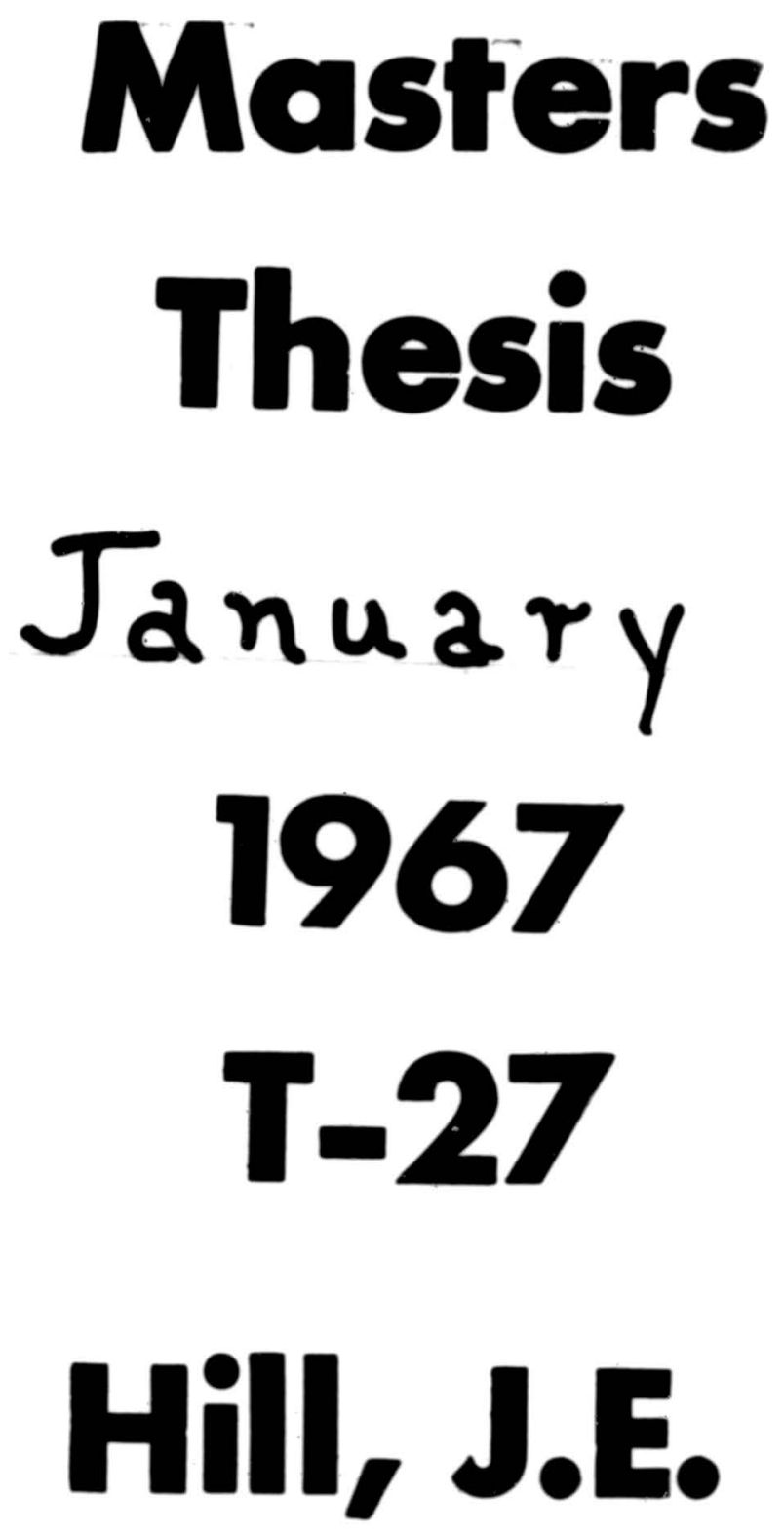


\section{MIC:ROF ILAFD}<smiles>[131I][131I]</smiles>

thes

IDNIVERSITY

\section{of}

MISSOLIRI

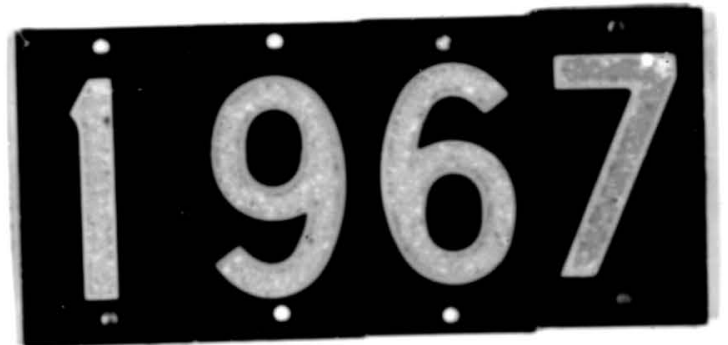

